\title{
Erect bifoliate species of Microporella (Bryozoa, Cheilostomata), fossil and modern
}

\author{
Emanuela DI MARTINO ${ }^{1, *}$, Paul D. TAYLOR ${ }^{2} \&$ Dennis P. GORDON ${ }^{3}$ \\ ${ }^{1}$ Natural History Museum, University of Oslo, Norway. \\ ${ }^{2}$ Departments of Earth and Life Sciences, Natural History Museum, London, United Kingdom. \\ ${ }^{3}$ National Institute of Water \& Atmospheric Research, Wellington, New Zealand. \\ *Corresponding author: e.d.martino@nhm.uio.no \\ ${ }^{2}$ Email: p.taylor@nhm.ac.uk \\ ${ }^{3}$ Email: dennis.gordon@niwa.co.nz \\ ${ }^{1}$ urn:1sid:zoobank.org:author:A7905C48-FF37-4D27-BCCE-F0560AF040A2 \\ ${ }^{2}$ urn:1sid:zoobank.org:author:7AFF2929-DF5B-46B2-94E6-B26B396CC2C8 \\ ${ }^{3}$ urn:1sid:zoobank.org:author:DD9C0F3A-8512-4AC8-B395-7687CE3FC565
}

\begin{abstract}
Microporella Hincks, 1877 is one of the most diverse genera of cheilostome bryozoans, containing more than 150 named species. Distributed globally since the early Miocene, the majority of species of Microporella have sheet-like colonies encrusting hard and/or ephemeral substrates, while a limited number of species have erect bifoliate colonies starting from an encrusting base. Herein, the four nominal species of erect bifoliate Microporella (M. bifoliata, M. hastigera, M. hyadesi and M. ordo) are revised, and one new Pliocene (M. tanyae sp. nov.) and three new Recent species (M. ordoides sp. nov., M. lingulata sp. nov. and M. modesta sp. nov.) are formally described. Furthermore, the lectotype and paralectotypes were designated for M. bifoliata and M. hastigera. An additional Recent species, Microporella sp. 1, is also described and illustrated but left in open nomenclature owing to the absence of ovicells in the single available fragment. Although the molecular phylogeny of Microporella has yet to be resolved, the diversity of character states present among the erect bifoliate species described here suggests that this colony growth-form is not monophyletic but has evolved on multiple occasions.
\end{abstract}

Keywords. Taxonomy, new species, colony growth-form, Recent, Neogene.

Di Martino E., Taylor P.D. \& Gordon D.P. 2020. Erect bifoliate species of Microporella (Bryozoa, Cheilostomata), fossil and modern. European Journal of Taxonomy 678: 1-31. https://doi.org/10.5852/ejt.2020.678

\section{Introduction}

Microporella Hincks, 1877 is one of the most speciose genera of all cheilostome bryozoans, with more than 150 species described to date, both living and fossil (Taylor \& Mawatari 2005). The distinctive zooidal morphology of this genus makes it relatively easy to recognize, but species determination is far more challenging as differences between congeneric species can be very subtle (e.g., Suwa \& Mawatari 1998; Harmelin et al. 2011). Furthermore, adequate descriptions and illustrations are available for only 
a small proportion of the nominal species. In all species of Microporella, autozooids have a porous frontal shield and a semielliptical orifice beneath which there is an ascopore opening into the ascus. The ascopore varies in shape from circular to elliptical, reniform or crescentic according to species. One avicularium, or less often a pair of avicularia, is normally present proximolaterally or laterally of the autozooidal orifice. Avicularian mandibles in living species may be short, or long and setose.

The great majority of species of Microporella have multiserial, single-layered colonies that encrust a variety of substrates, including shells, rocks, algae and seagrasses. Erect vincularian colonies with branches of circular cross-section are unknown in Microporella, although a genus with an almost identical zooidal morphology - Diporula Hincks, 1879 - does possess this colony growth-form. However, erect bifoliate colonies, with branches or fronds formed of two layers of zooids back-to-back, characterize four previously described species of Microporella: M. bifoliata Ulrich \& Bassler, 1904 from the Miocene of the USA; M. hastigera (Busk, 1884), a Recent North Atlantic species; M. hyadesi (Jullien, 1888), a Recent subantarctic species; and M. ordo Brown, 1952, originally described from the Pleistocene of New Zealand but since found living there today. As part of a broad survey of Microporella (see Taylor \& Mawatari 2005), one fossil and three Recent undescribed bifoliate species of Microporella were discovered in existing collections at the Natural History Museum in London, UK (NHMUK) and the National Institute of Water and Atmospheric Research, Wellington, New Zealand (NIWA): M. tanyae sp. nov. from Pliocene deposits in Virginia (USA), M. ordoides sp. nov. and M. lingulata sp. nov. collected in New Zealand waters, and M. modesta sp. nov. from the Mediterranean off Algeria. An additional, fourth living species was recently collected during a cruise southwest of the South Island of New Zealand off Puysegur Point. Although there is enough to morphogically distinguish this species from all other bifoliate congeners, it is left in open nomenclature owing to the availability of a single, non-ovicellate specimen.

The aim of the current paper is to revise the four established bifoliate species of Microporella, and describe and illustrate the four new species plus the additional species left in open nomenclature.

\section{Material and methods}

This study is based on both fossil and recent material housed in museum collections as well as newly collected specimens.

Scanning electron microscopy (SEM) was conducted on uncoated specimens using LEO VP-1455 and JEOL IT500 microscopes operated at low-vacuum and back-scattered electron mode at the Natural History Museum, London, and an Hitachi TM4000plus Tabletop at the Natural History Museum, Oslo. JoAnn Sanner provided SEM micrographs of the syntypes of Microporella bifoliata Ulrich \& Bassler, 1904 (USNM 68592).

Morphometric measurements were taken from SEM images using the image processing program ImageJ (available from https://imagej.nih.gov/). Abbreviations for the measurements are:
$\mathrm{AvL}=$ avicularium length
$\mathrm{AvW}=$ avicularium width
$\mathrm{OL}=$ orifice length
$\mathrm{OW}=$ orifice width
$\mathrm{OvL}=$ ovicell/ooecium length
$\mathrm{OvW}=$ ovicell/ooecium width
$\mathrm{ZL} \quad=$ autozooid length
$\mathrm{ZW}=$ autozooid width 
Type material of the new species and illustrated specimens are housed at the following institutions: Natural History Museum, London; National Institute of Water and Atmospheric Research, Wellington, New Zealand. The voucher specimen BLEED 151 is stored at the Natural History Museum, University of Oslo.

\section{Repositories}

NHMUK = Natural History Museum London, UK

NHM-UIO $=$ Natural History Museum, University of Oslo, Oslo, Norway

NIWA $=$ National Institute of Water and Atmospheric Research, Wellington, New Zealand

USNM = Smithsonian Institution, National Museum of Natural History, Washington, USA

\section{Results}

Phylum Bryozoa Ehrenberg, 1831

Class Gymnolaemata Allman, 1856

Order Cheilostomata Busk, 1852

Superfamily Schizoporelloidea Jullien, 1883

Family Microporellidae Hincks, 1879

Genus Microporella Hincks, 1877

Microporella bifoliata Ulrich \& Bassler, 1904

Fig. 1; Table 1

Microporella? bifoliata Ulrich \& Bassler, 1904: 417, pl. 103, figs 6-8.

Microporella? bifoliata - Canu \& Bassler 1923: 121, pl. 20, figs 7-11.

\section{Material examined}

Lectotype (designated here)

USA - Syntype of Microporella bifoliata Ulrich \& Bassler, 1904; Maryland, Cordova; Miocene; Choptank Formation; USNM 68592A (Fig. 1A-B).

Paralectotype (designated here)

USA - Syntype of Microporella bifoliata Ulrich \& Bassler, 1904; Maryland, Cordova; Miocene; Choptank Formation; USNM 68592B (Fig. 1C-D).

\section{Other material}

USA -4 specimens, syntypes of Microporella bifoliata Ulrich \& Bassler, 1904; Maryland, Cordova; Miocene; Choptank Formation; USNM 68592C to 68592F.

\section{Description}

Colony. Erect with bifoliate fronds up to several $\mathrm{cm}$ wide, curved; colony base and interzooidal communication not observed.

Autozooids. Distinct, separated by narrow grooves, rectangular, longer than wide (mean L/W $=1.76$ ). Frontal shield flat; marginal areolae typically numbering about $16(12-18)$, variable in size $(15-40 \mu \mathrm{m})$, funnel-shaped, sometimes subdivided internally; reduced number of non-marginal pseudopores, placed more centrally on the frontal shield, irregularly spaced.

PRIMARY ORIFICE. Terminal, semielliptical, widest medially, hingeline slightly concave, without teeth or condyles; oral spines lacking; no peristome. 
ASCOPORE FIELD. A narrow, raised area of gymnocystal calcification beneath level of adjacent frontal shield but at approximately same level as orifice, located very close to its hingeline; elliptical, ca $35 \times$ $50 \mu \mathrm{m}$, distal margin with projecting, semielliptical tongue leaving a crescent-shaped opening, ca $10 \times$ $30 \mu \mathrm{m}$, with radial spines.

Avicularium. Single, located at the same level of ascopore, oriented laterally; crossbar complete; opesia semielliptical; rostrum subtriangular, the distal end a little rounded, not channelled.
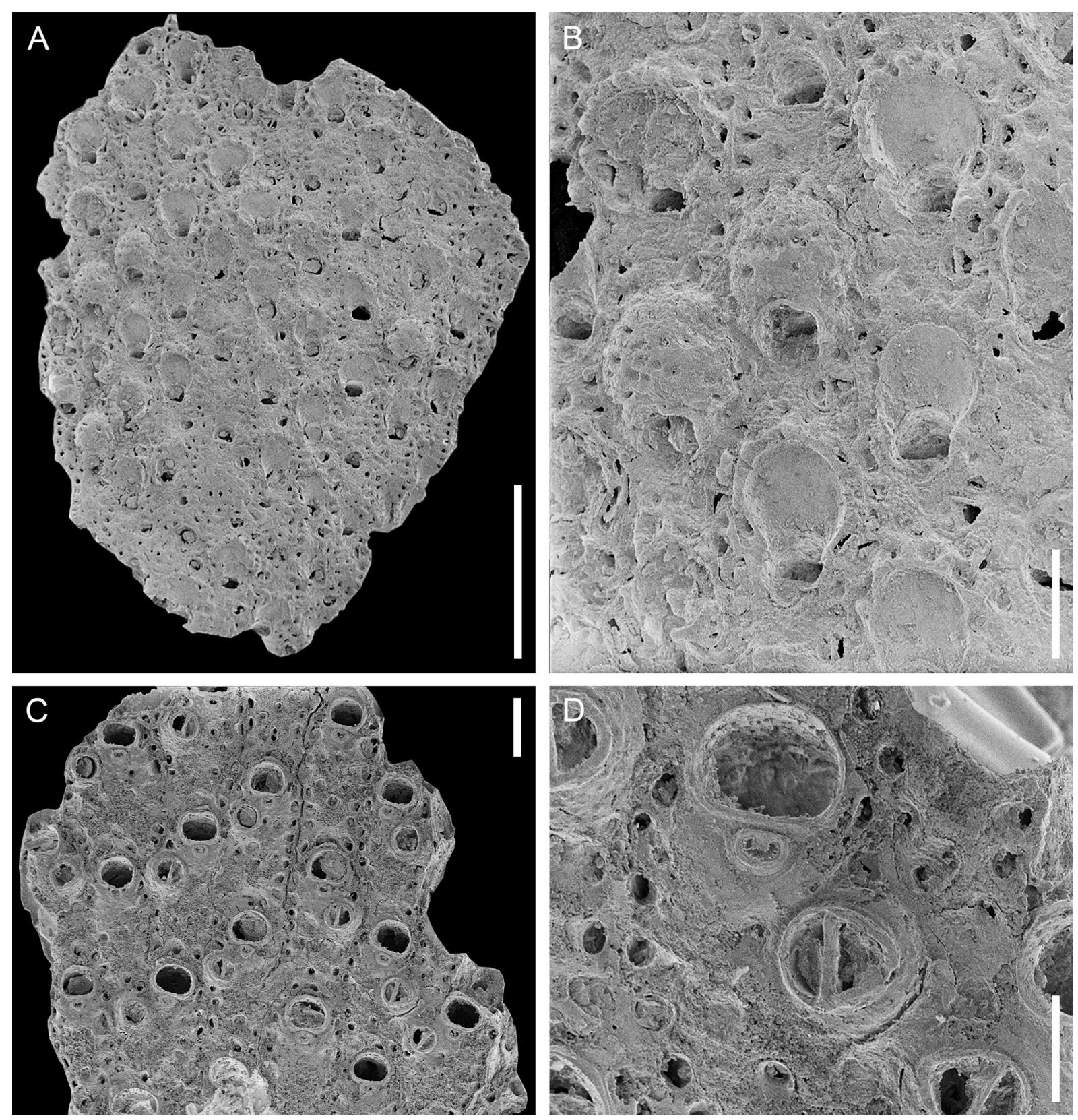

Fig. 1. Microporella bifoliata Ulrich \& Bassler, 1904, Miocene, Choptank Formation, Maryland, USA. A-B. Lectotype USNM 68592A. A. General view of the branch fragment. B. Group of zooids, mostly ovicellate. C-D. Paralectotype USNM 68592B. C. Group of autozooids. D. Close-up of an autozooid. Scale bars: $\mathrm{A}=1 \mathrm{~mm} ; \mathrm{B}-\mathrm{C}=200 \mu \mathrm{m} ; \mathrm{D}=100 \mu \mathrm{m}$. 
Table 1. Measurements in $\mu \mathrm{m}$ of Microporella bifoliata Ulrich \& Bassler, 1904, Miocene, Choptank Formation, Maryland, USA; lectotype USNM 68592A, paralectotype USNM 68592B.

\begin{tabular}{lccccc}
\hline & N (zooids, colonies) & Mean & SD & Min & Max \\
\hline ZL & 16,2 & 509 & \pm 73 & 385 & 662 \\
ZW & 16,2 & 290 & \pm 27 & 245 & 330 \\
OL & 10,2 & 91 & \pm 4 & 85 & 98 \\
OW & 10,2 & 114 & \pm 9 & 102 & 126 \\
AvL & 16,2 & 104 & \pm 12 & 78 & 122 \\
AvW & 16,2 & 86 & \pm 14 & 62 & 116 \\
OvL & 8,1 & 243 & \pm 12 & 231 & 261 \\
OvW & 8,1 & 273 & \pm 27 & 238 & 312 \\
\hline
\end{tabular}

Ovicell. Prominent, circular in outline, not personate and not obscuring orifice; calcification similar to frontal shield; pseudopores variable in number, scattered over entire surface, variably spaced.

\section{Remarks}

This extinct species was described from the Miocene (Choptank Formation 12.6-14.4 Ma; Andrews 1988) of Maryland (Fig. 1).

The form of the mandible is not known in this fossil species, but the fact that the avicularia have closed distal ends without channels may suggest that mandibles were not setose and had a shape identical to that of the rostrum.

Microporella tanyae sp. nov. urn:lsid:zoobank.org:act:324E8E55-E5FC-489A-843E-322D7F3A4FAB

Figs 2-3; Table 2

\section{Diagnosis}

Colony erect, bifoliate; branches broad. Autozooids rhomboidal. Frontal shield granular, sparsely pseudoporous. Orifice transversely D-shaped; hingeline straight, smooth; oral spines lacking. Ascopore elliptical, opening crescentic with projecting tongue and radial spines. Avicularium single, placed level with ascopore, oriented distolaterally; crossbar complete; opesia semielliptical; rostrum channelled. Ovicells not personate.

\section{Etymology}

Named after Dr Tanya Knowles who collected the specimens in 2006.

\section{Material examined}

\section{Holotype}

USA • Virginia, Chuckatuck; 2006; Tanya Knowles leg.; Pliocene; Upper Yorktown Formation; NHMUK PI BZ 8890 (Fig. 3).

\section{Other material}

USA • 1 specimen; Virginia, lower York County, Krause Pit; Edgar Campbell Col.; Pliocene; Yorktown Formation; USNM 387373 (Fig. 2). 


\section{Description}

CoLONy. Starting with an encrusting unilaminar and multiserial base, later becoming erect with bifoliate fronds up to several $\mathrm{cm}$ wide; interzooidal communication not observed.

Autozooids. Distinct, separated by narrow grooves, rhomboidal, longer than wide (mean L/W=1.39). Frontal shield moderately convex, finely and densely granular; marginal areolae typically numbering about $10(8-12)$, variable in size $(15-60 \mu \mathrm{m})$, funnel-shaped, sometimes subdivided internally; up to about eight non-marginal pseudopores, morphologically very similar to areolar pores, generally placed more centrally on the frontal shield at the same level as the avicularium or slightly below, irregularly spaced, sometimes internally subdivided.

Primary ORIFICE. Terminal, transversely D-shaped, widest medially, hingeline straight, smooth, without teeth or condyles; oral spines lacking; no peristome.

ASCOPORE FIELD. A narrow, raised area of gymnocystal calcification beneath level of adjacent frontal shield but at approximately same level as orifice, located very close to its hingeline; elliptical, ca 30-

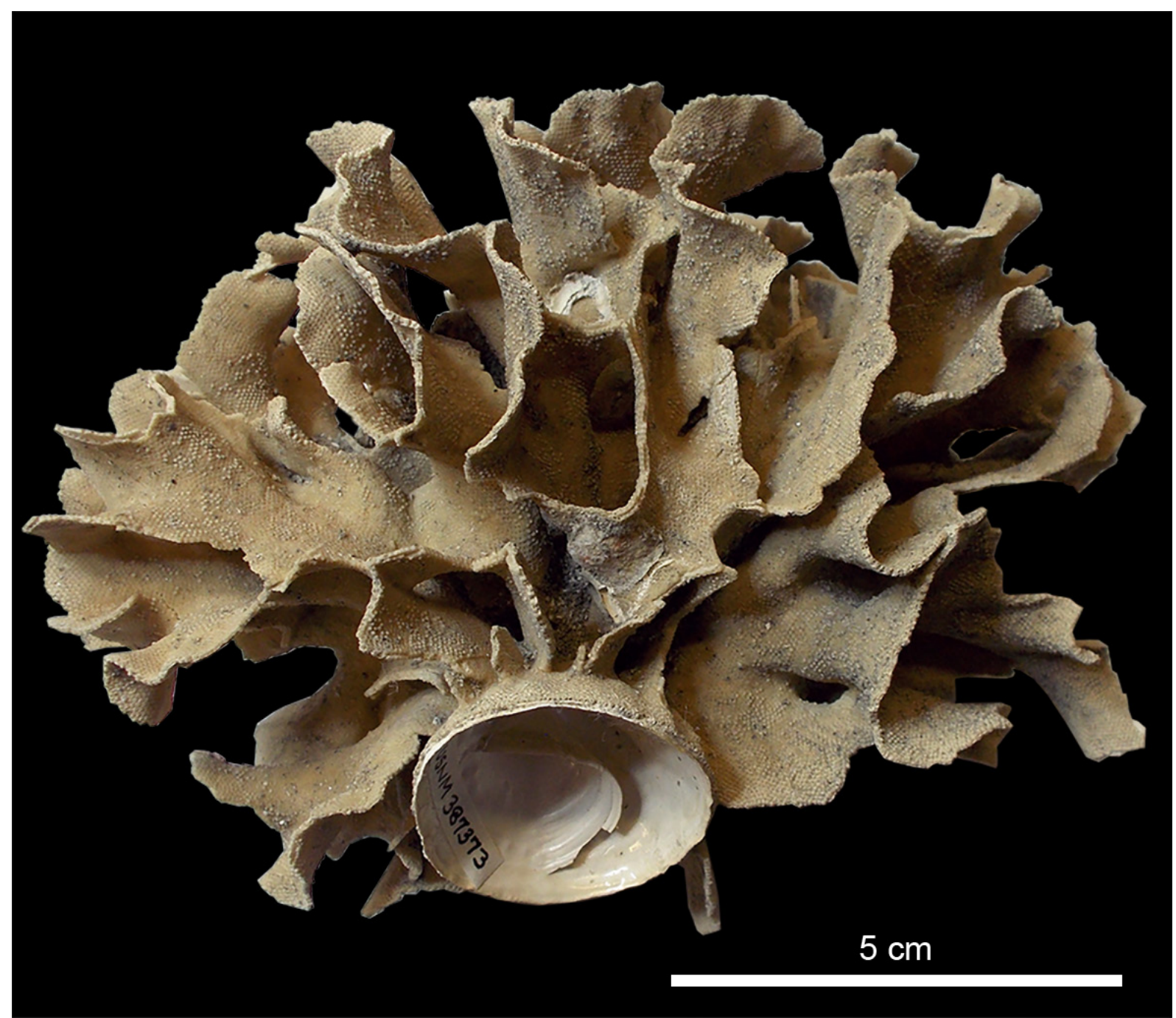

Fig. 2. Colony of Microporella tanyae sp. nov. USNM 387373, Pliocene, Yorktown Formation, Krause Pit, lower York County, Virginia, USA (Edgar Campbell Col.). 
Table 2. Measurements in $\mu \mathrm{m}$ of Microporella tanyae sp. nov., Pliocene, Yorktown Formation, Virginia, USA; holotype NHMUK PI BZ 8890.

\begin{tabular}{lccccc}
\hline & N (zooids, colonies) & Mean & SD & Min & Max \\
\hline ZL & 16,1 & 526 & \pm 53 & 441 & 621 \\
$\mathbf{Z W}$ & 16,1 & 378 & \pm 51 & 307 & 466 \\
OL & 12,1 & 115 & \pm 5 & 106 & 122 \\
OW & 12,1 & 142 & \pm 5 & 137 & 152 \\
AvL & 16,1 & 130 & \pm 9 & 116 & 147 \\
AvW & 16,1 & 94 & \pm 6 & 85 & 102 \\
OvL & 5,1 & 250 & \pm 16 & 235 & 276 \\
OvW & 5,1 & 349 & \pm 31 & 304 & 389 \\
\hline
\end{tabular}

$35 \times 50-60 \mu \mathrm{m}$, distal margin with projecting, semielliptical tongue leaving a crescent-shaped opening, ca 5-10 $\times 25-35 \mu \mathrm{m}$, with radial spines.

Avicularium. Single, located between level of ascopore and lateral corner of rhomboidal autozooid, oriented laterally to slightly distolaterally; crossbar complete; opesia semielliptical; rostrum subtriangular, channelled.
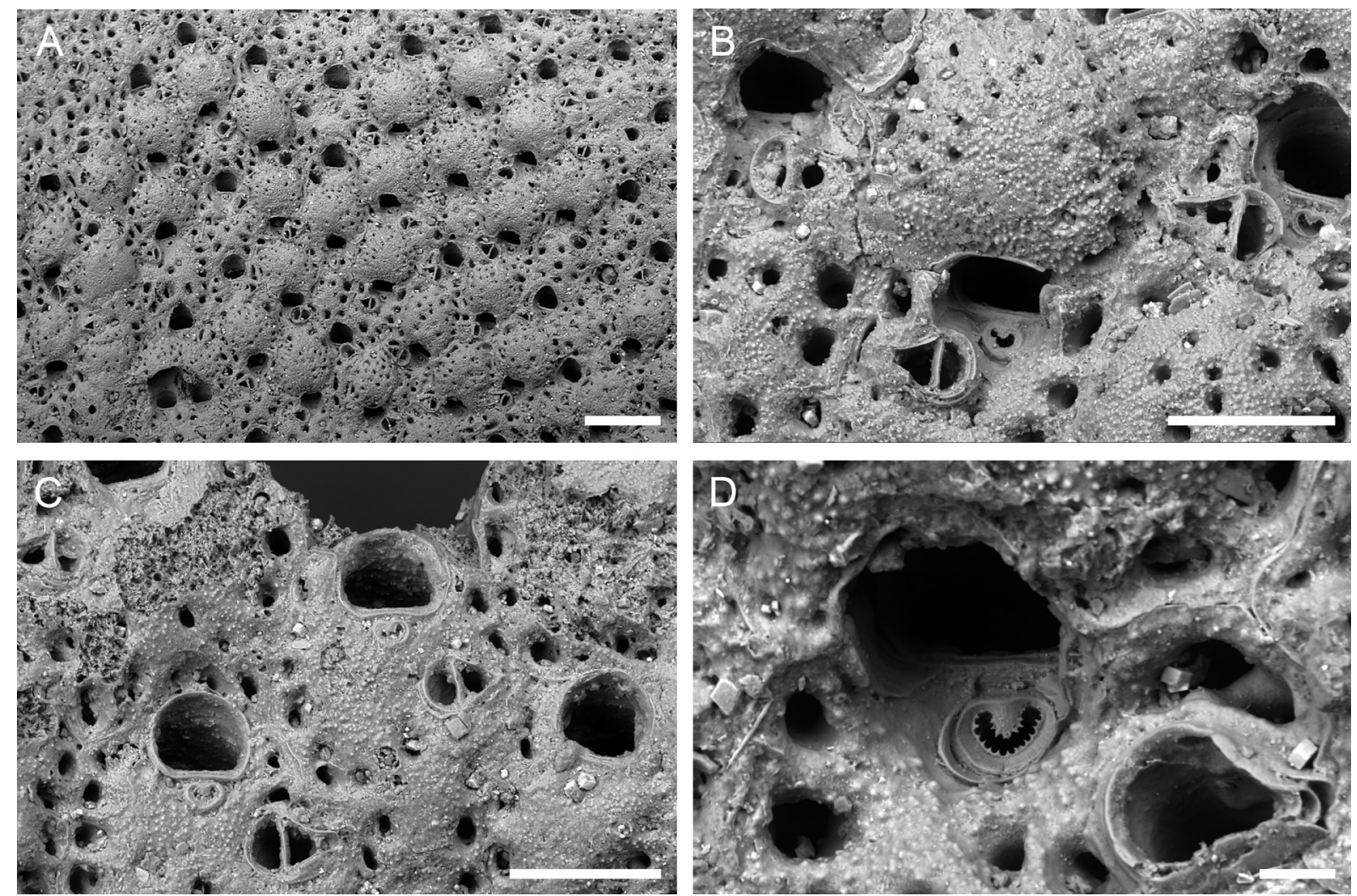

Fig. 3. Microporella tanyae sp. nov., holotype, NHMUK PI BZ 8890, Pliocene, Yorktown Formation, Virginia, USA. A. Group of ovicellate and non-ovicellate zooids. B. Close-up of an ovicell. C. Closeup of an autozooid. D. Close-up of the ascopore and avicularium with intramural buds. Scale bars: $\mathrm{A}=$ $400 \mu \mathrm{m} ; \mathrm{B}-\mathrm{C}=200 \mu \mathrm{m} ; \mathrm{C}=200 \mu \mathrm{m} ; \mathrm{D}=40 \mu \mathrm{m}$. 
Ovicell. Prominent, circular in outline, not personate and not obscuring orifice; calcification similar to frontal shield, impinging on avicularium of distal autozooid; pseudopores variable in number, confined to marginal areas.

\section{Remarks}

This extinct species was found in the Pliocene of Virginia. Although very similar to the Miocene Microporella bifoliata, the new Pliocene species shows slightly shorter but wider, and consequently squatter, autozooids with larger orifices, larger avicularia and broader ovicells. Additionally, the rostrum in $M$. tanyae sp. nov. narrows distinctly immediately distal to the crossbar, which does not seem to be the case in M. bifoliata specimens, and the orifice seems to be more clearly D-shaped with the proximal margin somewhat straighter.

Microporella hastigera (Busk, 1884)

Figs 4-5; Table 3

Flustramorpha hastigera Busk, 1884: 136, text-fig. 40, pl. 21, figs 7, 7a-c.

Diporula hastigera - Waters 1888: 23, pl. 3, figs 28-29. — Jullien \& Calvet 1903: 51, pl. 1, fig. 3, pl. 6, fig. 3. - Calvet in Jullien \& Calvet 1903: 129. — Calvet 1907: 407.

Microporella hastigera - Calvet 1931: 87. — d'Hondt 1975: 577 (listed).

\section{Material examined}

Lectotype (designated here)

AZORES - Unbleached branch fragment figured by Busk (1884: pl. 21, fig. 7a); near Pico Island;

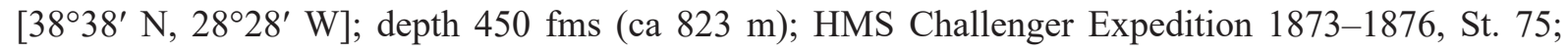
volcanic mud; NHMUK 1887.12.9.547 (Fig. 4).

Paralectotype (designated here)

AZORES • Bleached branch fragment; same collection data as for lectotype; NHMUK 1887.12.9.549a (Fig. 5).

\section{Description}

Colony. With an encrusting unilaminar and multiserial base, later becoming erect bilaminar, robust branching (adeoniform); branches narrow, 2-3 mm wide with usually 4-5 but up to eight linear series of alternating zooids on each side; interzooidal communication via multiporous septula.

Autozooids. Rhomboidal to hexagonal, longer than wide (mean $\mathrm{L} / \mathrm{W}=1.21$ ). Frontal shield relatively flat to moderately convex, entirely covered by distinct nodules of varying shape with 30-35 pseudopores (diameter 5-15 $\mu \mathrm{m}$ ) intercalated between them, plus 5-10 round marginal areolar pores, larger than frontal pores (diameter 20-45 $\mu \mathrm{m}$ ); except for a single areolar pore distal to avicularium rostrum, area between proximal margin of the orifice and ascopore field and directly proximally to avicularium rostrum usually devoid of pores.

PRIMARY ORIFICE. Transversely D-shaped with a straight, distinctly crenulated hingeline; in each corner a short, blunt denticle directed distally; distolateral orificial rim with numerous low rounded and irregularly distributed denticles of variable size; operculum smooth but with a broad and slightly bent transverse depression in the centre; three or four distal oral spines (diameter 15-20 $\mu \mathrm{m}$ ); no peristome.

ASCOPORE FIELD. Outlined by a low rim and a narrow, raised band of gymnocystal calcification, located at ca $65 \mu \mathrm{m}$ from hingeline of the orifice, slightly displaced to the side by the avicularium and often 
obliquely aligned; gymnocystal field elliptical, ca 50-60 × 70-80 $\mu \mathrm{m}$; distal margin with median, subrectangular, projecting tongue leaving a C-shaped opening, ca $10 \times 50 \mu \mathrm{m}$, delimited by finely spinose margins.

AvicUlarium. Single, placed in close proximity of and lateral or proximolateral to ascopore; rostrum directed distolaterally, broadly triangular with an open funnelled tip and thin raised lateral margins,
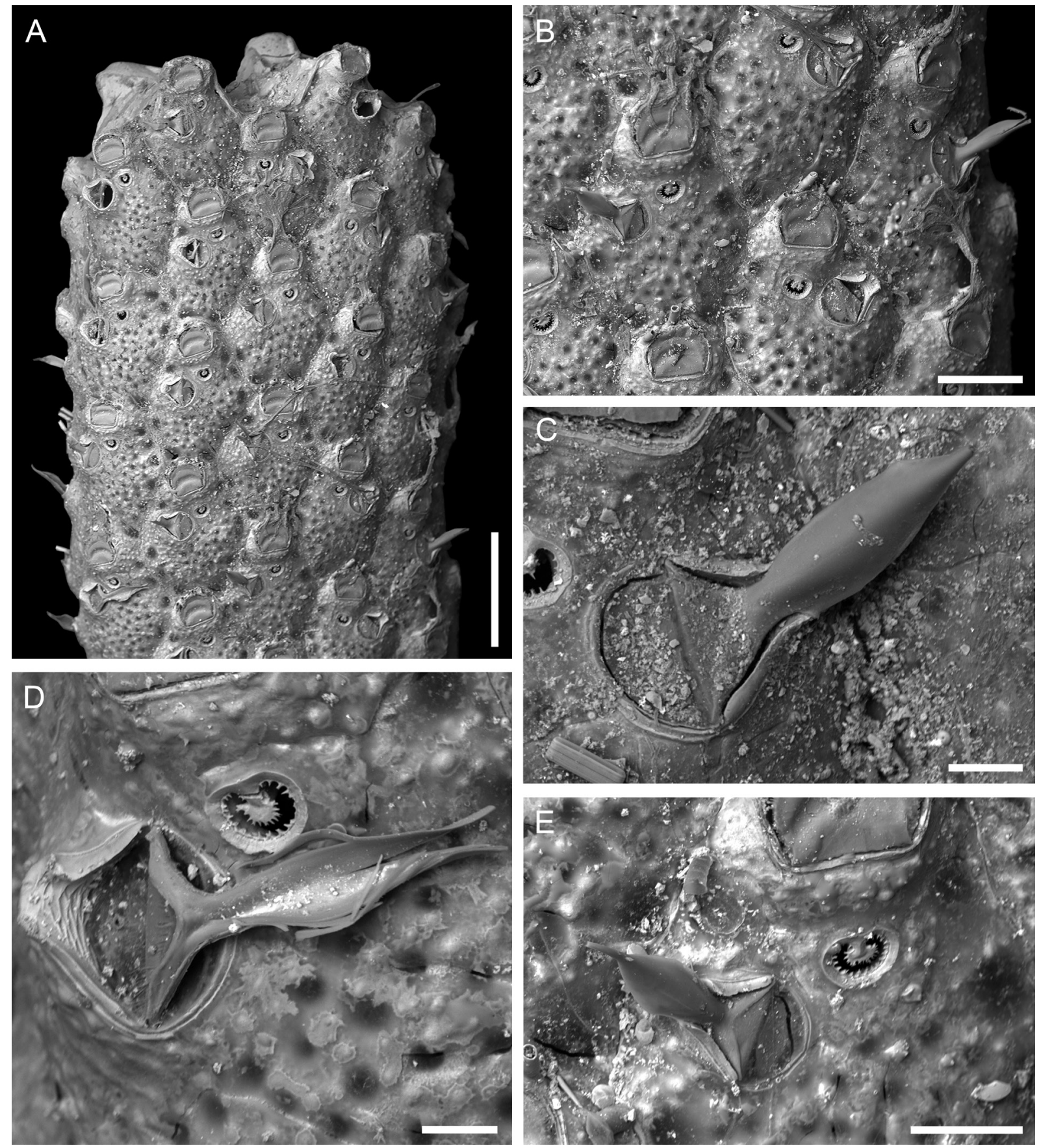

Fig. 4. Microporella hastigera (Busk, 1884), lectotype, NHMUK 1887.12.9.547 (unbleached), Recent, Challenger Expedition, St. 75. A. Group of zooids at the branch tip. B. Close-up of autozooids. C-E. Close-ups of the ascopore and adventitious avicularium with the lanceolate mandible either closed (C, E) or open (D). Scale bars: A = 500 $\mu \mathrm{m} ; \mathrm{B}=200 \mu \mathrm{m} ; \mathrm{C}-\mathrm{D}=50 \mu \mathrm{m} ; \mathrm{E}=100 \mu \mathrm{m}$. 

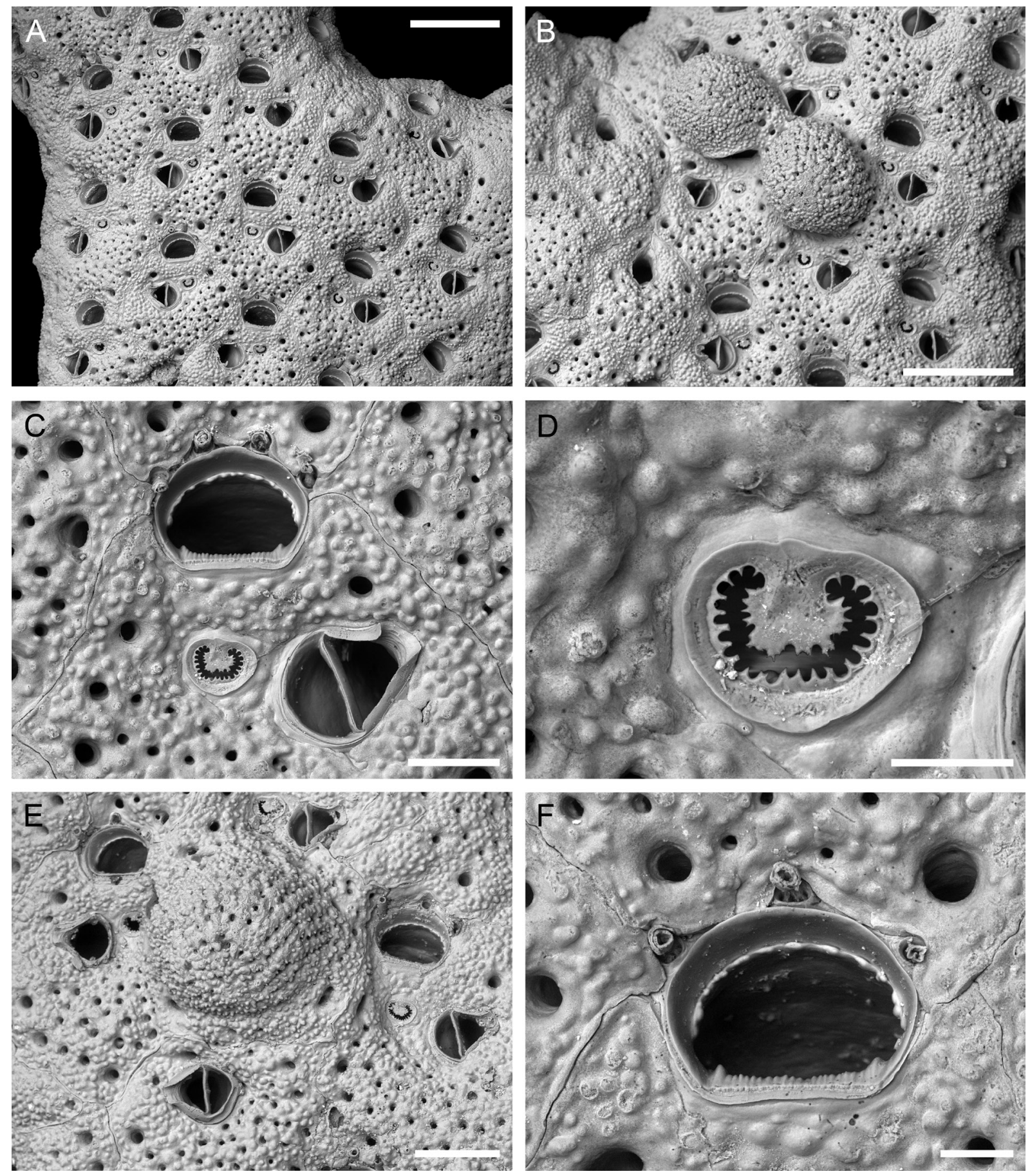

Fig. 5. Microporella hastigera (Busk, 1884), paralectotype, NHMUK 1887.12.9.549a (bleached), Recent, Challenger Expedition, St. 75. A. Group of zooids at branch bifurcation. B. Close-up of two ovicellate zooids with coalescent ovicells. C. Close-up of an orifice with four oral spine bases distally, ascopore and avicularium. D. Close-up of the ascopore. E. Ovicellate zooid with sealed orifice. F. Closeup of an orifice with three oral spine bases distally. Scale bars: $A-B=400 \mu \mathrm{m} ; \mathrm{C}=100 \mu \mathrm{m} ; \mathrm{D}=40 \mu \mathrm{m}$; $\mathrm{E}=200 \mu \mathrm{m} ; \mathrm{F}=50 \mu \mathrm{m}$. 
Table 3. Measurements in $\mu \mathrm{m}$ of Microporella hastigera (Busk, 1884), Recent, Challenger Expedition, St. 75; lectotype NHMUK 1887.12.9.547 and paralectotype NHMUK 1887.12.9.549a.

\begin{tabular}{lccccc}
\hline & N (zooids, colonies) & Mean & SD & Min & Max \\
\hline ZL & 25,2 & 604 & \pm 51 & 541 & 703 \\
$\mathbf{Z W}$ & 25,2 & 497 & \pm 48 & 400 & 572 \\
OL & 15,2 & 129 & \pm 7 & 115 & 138 \\
OW & 15,2 & 165 & \pm 8 & 145 & 175 \\
AvL & 25,2 & 156 & \pm 11 & 127 & 176 \\
AvW & 25,2 & 132 & \pm 6 & 124 & 145 \\
OvL & 3,1 & 399 & \pm 13 & 388 & 413 \\
OvW & 3,1 & 436 & \pm 32 & 414 & 473 \\
\hline
\end{tabular}

slightly acute to frontal plane; mandible lanceolate, significantly exceeding length of rostrum, ca $230 \mu \mathrm{m}$ long, abruptly decreasing in width between crossbar and rostrum and slightly widening distal to rostrum before thinning again, the distal third or quarter very narrow and downcurved; proximal and distal opesia semicircular, divided by a straight and thin but deep crossbar.

Ovicells. Globular, entirely obscuring the orifice; surface densely nodular and with numerous pseudopores seemingly aligned in radial rows, the proximolateral margins joining the proximolateral orifice corners, opening arched above proximal orifice margin, often equipped with a slightly projecting lip.

\section{Remarks}

This species was originally recorded from off western and northern Pico Island (Azores, central Atlantic) from depths between 80 and $820 \mathrm{~m}$. During the French Biaçores expedition it was also reported from around the islands of Flores (105-170 m), Graciosa (190-406 m), São Jorge (245 m), Terceira (90$220 \mathrm{~m}$ ) and São Miguel (61-550 m), as well as the Formigas Islets south of São Miguel (190-220 m) (d'Hondt 1975). Previous records of this species, especially those pre-dating the advent of scanning electron microscopy (e.g., Calvet (1931) from Cape Verde Islands at $52 \mathrm{~m}$ depth), need to be revised.

Microporella hyadesi (Jullien, 1888)

Fig. 6; Table 4

Fenestrulina hyadesi Jullien, 1888: 44, pl. 4, fig. 7 (given as Fenestrula in text but Fenestrulina on plate and caption).

Microporella hyadesi-López-Gappa 1975: 435, pl. 1, fig. 1, pl. 2, fig. 3. — López-Gappa \& Lichtschein 1990: 26, pl. 8, fig. 3. - Hayward \& Ryland 1990: 1282, fig. 10a. — Moyano 2000: table 1.

non Microporella hyadesi - Brown 1952: 254, figs 186-187.

\section{Material examined}

FALKLAND ISLANDS • 1 specimen; depth 74-75 m; 24 Mar. 1927; Discovery Expedition, St. WS 84; Recent; NHMUK 1990.10.22.14 (Fig. 6A-D) • 1 specimen; depth 166 m; 20 Jul. 1928; Discovery Expedition, St. WS 249; Recent; NHMUK 1990.10.10.25 (Fig. 6E-F) 1 specimen; west end of Magellan Strait; depth 66 m; 16 Mar. 1934; Discovery Expedition, St. 1321; Recent; NHMUK 1990.10.31.12 (Fig. 6G). 
Table 4. Measurements in $\mu \mathrm{m}$ of Microporella hyadesi (Jullien, 1888), Recent, Discovery Expedition; NHMUK 1990.10.22.14, NHMUK 1990.10.31.12.

\begin{tabular}{lccccc}
\hline & N (zooids, colonies) & Mean & SD & Min & Max \\
\hline ZL & 22,2 & 741 & \pm 84 & 662 & 972 \\
ZW & 22,2 & 443 & \pm 45 & 359 & 506 \\
OL & 22,2 & 110 & \pm 4 & 102 & 119 \\
OW & 22,2 & 190 & \pm 13 & 167 & 225 \\
AvL & 22,2 & 114 & \pm 8 & 100 & 127 \\
AvW & 22,2 & 101 & \pm 11 & 86 & 125 \\
OvL & 22,2 & 465 & \pm 38 & 394 & 543 \\
OvW & 22,2 & 472 & \pm 29 & 426 & 527 \\
\hline
\end{tabular}

\section{Description}

Colony. Erect, bifoliate, broad branches fused at edges to form a boxwork colony; growing edge intermediate between a smooth and a stepped edge; interzooidal communication not observed.

Autozooids. Rounded rectangular to hexagonal, longer than wide (mean $\mathrm{L} / \mathrm{W}=1.67$ ), distinct with interzooidal boundaries marked by thin band of slightly raised calcification on either side of a narrow groove. Frontal shield flat to very slightly convex, pustulose; marginal areolar pores numbering about 10, elongate near growing edge, becoming smaller, equidimensional and almost indistinguishable from pseudopores, except for those at the proximolateral corners of the zooid which remain larger (diameter 20-40 $\mu \mathrm{m}$ ); pseudopores numerous (about 50), small (diameter 5-15 $\mu \mathrm{m}$ ), irregularly scattered among pustules.

ORIFICE. Transversely D-shaped, significantly wider than long, hingeline with about 20 equal-sized teeth; oral spines lacking.

ASCOPORE FIELD. A narrow band of gymnocystal calcification, positioned at approximately same level as orifice but slightly depressed relative to the adjacent frontal shield, located ca 50-60 $\mu \mathrm{m}$ from the orifice hingeline, separated from it by non-porous pustulose cryptocyst; circular to transversely elliptical

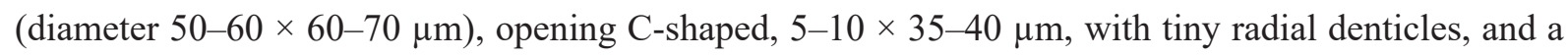
circular tongue projecting from distal edge.

Avicularium. Single, moderately large, present in the majority of autozooids, sometimes lacking in smaller zooids, especially immediately following row bifurcations; positioned level with the ascopore, oriented distolaterally, usually at about $60^{\circ}$ to the long axis of the autozooid; crossbar calcified; opesia semielliptical; rostrum short, broadly subtriangular with concave sides, the distal end rounded, distinct channel present. Mandible in dried material narrow, short (ca 50-65 $\mu \mathrm{m})$ and pointed triangular.

Ovicells. Very large, sometimes covering frontal shield of distal zooid as far as ascopore, bulbous, usually a little longer than wide, personate or semi-personate with variably-developed lobes extending proximally of orifice, calcification fabric similar to frontal shield but with finer pustulation, smoothly continuous with frontal shield of distal zooid; small pores scattered over entire surface, denser close to lateral and distal margins; secondary orifice of personate ovicellate zooids of reduced length, typically boat-shaped, the distal edge concave, the proximal edge convex. 


\section{Remarks}

This species has been recorded from the subantarctic, Cape Horn and Tierra del Fuego. Records from the Indian Ocean (Thornely 1912) and New Zealand (Brown 1952; Powell 1967) are probably misidentifications, the latter possibly M. ordo (see Di Martino et al. 2017: fig. 6). It is very common
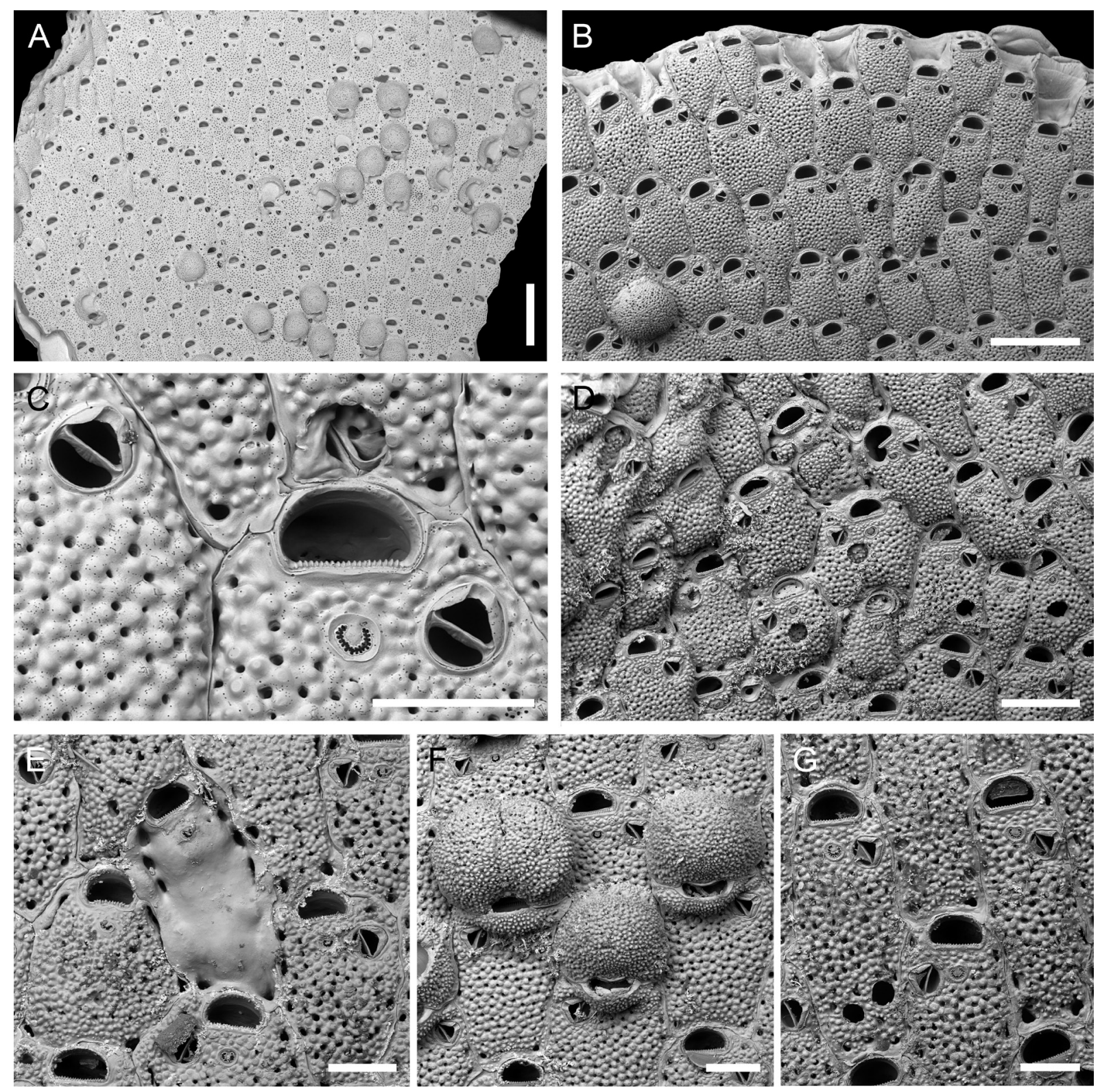

Fig. 6. Microporella hyadesi (Jullien, 1888), Recent, Discovery Expedition. A-D. NHMUK 1990.10.22.14. A. General view of a branch fragment. B. Group of zooids, one ovicellate, at the growing edge of the branch. Note the growing edge intermediate between a smooth and a stepped edge. C. Closeup of the orifice, ascopore and adventitious avicularia. Note also the borehole patched by an avicularium (top centre). D. Group of zooids showing several repared boreholes and sealed orifices. E-F. NHMUK 1990.10.10.25. E. Aberrant autozooid with smooth, non-pseudoporous frontal shield. F. Close-up of three ovicellate zooids, the ovicell on the left showing teratology. G. NHMUK 1990.10.31.12, autozooids with adventitious avicularia preserving triangular mandibles. Scale bars: A-B $=1 \mathrm{~mm}$; , $\mathrm{E}-\mathrm{G}=200 \mu \mathrm{m} ; \mathrm{D}=400 \mu \mathrm{m}$. 
in material from several widely dispersed Discovery Stations from depths of 49 to $341 \mathrm{~m}$ in the South Atlantic around Cape Horn, the Falkland Islands, Burdwood Bank, the southern Patagonian Shelf, Shag Rocks and South Georgia (Hayward \& Ryland 1990). Many of the colonies show extensive circular boreholes, about $0.12 \mathrm{~mm}$ in diameter, which penetrate autozooidal frontal shields and ovicells (Fig. 6CD). Similar boreholes were interpreted by Wilson \& Taylor (2006) as evidence of boring predation. Often the boring is repaired by a plug of calcification secreted from the underside, or by an adventitious avicularium (Fig. 6C). Bored zooids may possess an additional orificial rim with a new hingeline within the original orifice, representing intramural budding, or have a sealed orifice (Fig. 6D). Teratology was observed in both autozooids (Fig. 6E) and ovicells (Fig. 6F).

Microporella ordo Brown, 1952

Fig. 7; Table 5

Microporella ordo Brown, 1952: 257, figs 189-193.

Microporella ordo - Powell 1967: 291, text-fig. 54.

\section{Material examined}

Holotype

NEW ZEALAND • Wanganui, Castlecliff; NZGS Loc. 4013; late Pleistocene; Castlecliffian Horizon CU3 (ca 0.55 myr); NHMUK D36809 (figured in Di Martino et al. 2017: fig. 5).

Additional material (figured)

NEW ZEALAND • Fragment from large colony, bleached; Spirits Bay; Recent; NIWA 144880 (Fig. 7AC) • Fractured section; Recent; NIWA 144881 (Fig. 7D) • Fragment 2, unbleached; Spirits Bay; Recent; NIWA 144882 (Fig. 7E-F).

Additional material (not figured)

NEW ZEALAND • 1 specimen; [33.9655 ${ }^{\circ} \mathrm{S}, 171.7723^{\circ}$ E]; depth $92-96$ m; St. TAN1105/42; Recent; NIWA $73196 \bullet 2$ specimens; [37.5947 $\mathrm{S}, 178.8660^{\circ}$ E]; depth 56-58 m; St. TAN1108/239; Recent; NIWA 75495, $75499 \bullet 1$ specimen; [34.3780 $\left.\mathrm{S}, 172.7100^{\circ} \mathrm{E}\right]$; depth $48 \mathrm{~m}$; St. KAH9901/45; Recent; NIWA $99099 \cdot 1$ specimen; [34.3782 ${ }^{\circ} \mathrm{S}, 173.0265^{\circ}$ E]; depth 64-65 m; St. TAN0906/170; Recent; NIWA $56945 \cdot 1$ specimen; [34.3813 ${ }^{\circ} \mathrm{S}, 172.6618^{\circ}$ E]; depth 54 m; St. KAH9901/69; Recent; NIWA 99072 • 1 specimen; [34.3690 $\mathrm{S}, 172.8250^{\circ}$ E]; depth 55 m; St. KAH9901/25; Recent; NIWA 114233 • 1 specimen; [34.3600 ${ }^{\circ}$ S, $172.6968^{\circ}$ E]; depth 46 m; St. KAH9901/31; Recent; NIWA 128424.

\section{Description}

CoLONy. Erect, bifoliate, the largest about $110 \times 75 \mathrm{~mm}$, with broad branches fused at edges to form a boxwork colony; interzooidal communication via multiporous septula, elliptical, $55 \mu \mathrm{m}$ long by $45 \mu \mathrm{m}$ wide, with at least 12 circular pores ca $4 \mu \mathrm{m}$ in diameter, placed in the basal lateral walls on distolateral corners of autozooids.

AutozooIDs. Distinct with interzooidal boundaries marked by narrow grooves, rounded rectangular to hexagonal, longer than wide (mean $\mathrm{L} / \mathrm{W}=1.63$ ). Frontal shield flat to very slightly convex, pustulose, the pustules about 20-30 $\mu \mathrm{m}$ in diameter; marginal areolae numbering about 10 , elongate near growing edge (25-45 $\mu \mathrm{m}$ long by $15-20 \mu \mathrm{m}$ wide), becoming indistinguishable from frontal pores in older zooids; non-marginal pseudopores moderately large (diameter $8-18 \mu \mathrm{m}$ ), numbering about 20-30, arranged semi-regularly. 
DI MARTINO E. et al., Bifoliate species of the bryozoan Microporella

Table 5. Measurements in $\mu \mathrm{m}$ of Microporella ordo Brown, 1952, Recent, Spirits Bay, New Zealand; NIWA 144880, 144882.

\begin{tabular}{lccccc}
\hline & N (zooids, colonies) & Mean & SD & Min & Max \\
\hline ZL & 20,2 & 517 & \pm 31 & 457 & 557 \\
ZW & 20,2 & 318 & \pm 36 & 234 & 378 \\
OL & 20,2 & 96 & \pm 5 & 84 & 104 \\
OW & 20,2 & 151 & \pm 7 & 130 & 160 \\
AvL & 20,2 & 86 & \pm 7 & 72 & 107 \\
AvW & 20,2 & 80 & \pm 6 & 71 & 91 \\
OvL & 9,1 & 406 & \pm 26 & 362 & 446 \\
OvW & 9,1 & 390 & \pm 13 & 374 & 404 \\
\hline
\end{tabular}

OrIFICE. Semielliptical, significantly wider than long, hingeline straight to weakly concave, with about 15 teeth, equal in size except for slightly longer outer one or two pairs; oral spines lacking; folded back transverse vertical wall of distal zooid forming a slightly elevated crescent secondary rim above the distal margin of the primary orifice; operculum smooth.

ASCOPORE FIELD. As a raised area of gymnocystal calcification at approximately same level as orifice but beneath level of adjacent frontal shield, located moderately close to orifice hingeline, about 60-70 $\mu \mathrm{m}$ below, separated from it by non-porous pustulose cryptocyst; reniform to transversely elliptical, $45 \times$ $60 \mu \mathrm{m}$, opening heart-shaped, $25 \times 40 \mu \mathrm{m}$, covered by filigree sieve plate, a narrow, bifurcated tongue usually projecting from the distal edge.

Avicularium. Single, moderately large, present in the majority of autozooids, positioned level with or slightly distally of and almost abutting the ascopore, oriented distolaterally to almost laterally; crossbar complete; opesia semielliptical; rostrum short, teat-shaped, the distal end rounded, distinct channel present. Mandible in dried material with short (ca 90-110 $\mu \mathrm{m}$ ) pointed seta, narrow throughout, hooked on underside, lying across or a little proximal of ascopore when open.

OvicelLs. Very large, often covering frontal shield of distal zooid as far as ascopore, bulbous, subcircular or a little longer than wide, non-personate; calcification similar to frontal shield but with finer pustules, continuous with frontal shield of distal zooid; small pseudopores distributed across entire surface, more closely spaced compared to those on the frontal shield, radially aligned near margins; orifice of ovicellate zooids hidden in frontal view.

\section{Remarks}

The description given above and measurements in Table 5 are based on Recent examples of this species which show the morphology of the species better than the type and other fossil material. Although very similar to Microporella hyadesi in its general appearance, $M$. ordo is easily distinguished by its heartshaped ascopore with filigree sieve plate and narrow bifurcated tongue, in addition to the non-personate ovicells.

The present-day range of the species extends from NW of the Three Kings Islands at Middlesex Bank to Ranfurly Banks off East Cape, New Zealand (33.9-37.6 S; depth 46-96 m). 

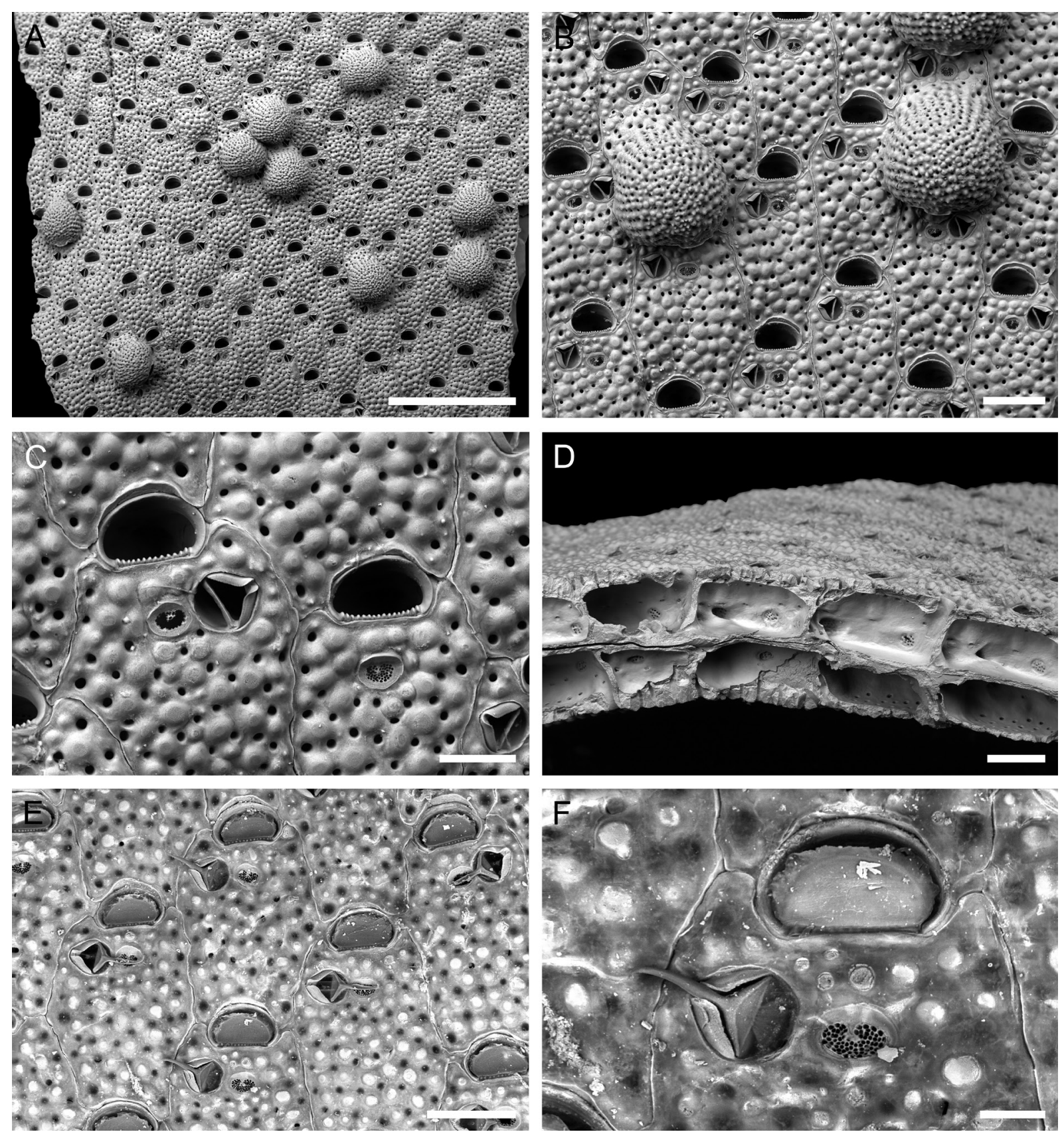

Fig. 7. Microporella ordo Brown, 1952, Recent, Spirits Bay, New Zealand. A-C. NIWA 144880. A. General view of a branch fragment. B. Group of ovicellate and non-ovicellate zooids. C. Close-up of two autozooids, that on the right with preserved filigree sieve plate. D. NIWA 144881, transversal view of the bifoliate branch showing multiporous septula. E-F. NIWA 144882. E. Group of unbleached autozooids showing opercula and thin, pointed avicularian mandibles. F. Close-up of the ascopore and the avicularian mandible. Scale bars: A $=1 \mathrm{~mm} ; \mathrm{B}, \mathrm{D}-\mathrm{E}=200 \mu \mathrm{m} ; \mathrm{C}=100 \mu \mathrm{m} ; \mathrm{F}=50 \mu \mathrm{m}$. 


\section{Microporella ordoides sp. nov. urn:1sid:zoobank.org:act:D2F60F45-FFFC-4BA0-9682-FD7CE56CBC64}

Fig. 8; Table 6

\section{Diagnosis}

Colony erect, bifoliate; branches narrow. Autozooids rhomboidal. Frontal shield pustulose, pseudoporous. Orifice semielliptical; hingeline with equal-sized teeth, the outermost smaller; oral spines lacking. Ascopore subcircular, opening horseshoe-shaped covered by a filigree sieve plate and a narrow tongue projecting from the distal edge. Avicularium single, placed level with ascopore, oriented distolaterally; crossbar complete; opesia semielliptical; rostrum channeled. Ovicells personate or semipersonate.

\section{Etymology}

Referring to its similarity with Microporella ordo Brown, 1952.

\section{Material examined}

\section{Holotype}

NEW ZEALAND - Bleached specimen; SE of Campbell Island on the Campbell Plateau; [52 56.4' S, $169^{\circ} 23^{\prime}$ E]; [159 m]; NZOI St. D35; Recent; NIWA 144883 (Fig. 8A-D).

Paratypes (unbleached specimens)

NEW ZEALAND - 1 specimen; SE of Campbell Island on the Campbell Plateau; [53.2333 ${ }^{\circ}$ S, $171.8000^{\circ}$ E]; [435 m]; St. F145; Recent; NIWA 119893 (Fig. 8E-F) • 1 specimen; SE of Campbell Island on the Campbell Plateau; [53.0917 $\mathrm{S}, 170.2167^{\circ} \mathrm{E}$ ]; [380 m]; St. F143; Recent; NIWA 144885 (not figured).

\section{Description}

Colony. Erect, bifoliate; the longest colony observed about $54 \mathrm{~mm}$ with the broadest frond about $15 \mathrm{~mm}$, consisting of more than 30 linear series of alternating zooids; growing edge stepped; interzooidal communications not observed.

AutozooIDs. Distinct with interzooidal boundaries marked by narrow grooves, often bordered by salient vertical walls, rhomboidal, longer than wide (mean $\mathrm{L} / \mathrm{W}=1.30$ ). Frontal shield convex, pustulose, the pustules about $20 \mu \mathrm{m}$ in diameter; marginal areolae usually 6 or fewer, elongate, elliptical to dropshaped, larger at corners of zooids ( $25-35 \mu \mathrm{m}$ long by $15 \mu \mathrm{m}$ wide); non-marginal pseudopores variable in size (diameter $3-15 \mu \mathrm{m}$ ), numbering over 50, arranged semi-regularly.

ORIFICE. Semielliptical, significantly wider than long, hingeline straight or somewhat convex, with about 17 teeth, equal-sized apart from the outermost few which are smaller; oral spines lacking; folded back transverse vertical wall of distal zooid forming a crescent above the distal part of the primary orifice.

ASCOPORE FIELD. As a raised area of gymnocystal calcification at approximately same level as orifice but beneath level of adjacent frontal shield, located moderately close to orifice hingeline, about $60-70 \mu \mathrm{m}$ below, separated from it by non-porous cryptocyst with smaller than average pustules; subcircular, 45$60 \mu \mathrm{m}$ in diameter, opening horseshoe-shaped, $10-15 \times 30-35 \mu \mathrm{m}$, covered by filigree sieve plate, a narrow, straight tongue usually projecting from the distal edge.

Avicularium. Single, moderately large, present in the majority of autozooids; positioned level with or slightly proximally of ascopore, oriented distolaterally; crossbar complete; opesia semielliptical; rostrum short, teat-shaped, the distal end rounded, distinct channel present. Mandible 160-180 $\mu \mathrm{m}$ long, narrow and pointed. 

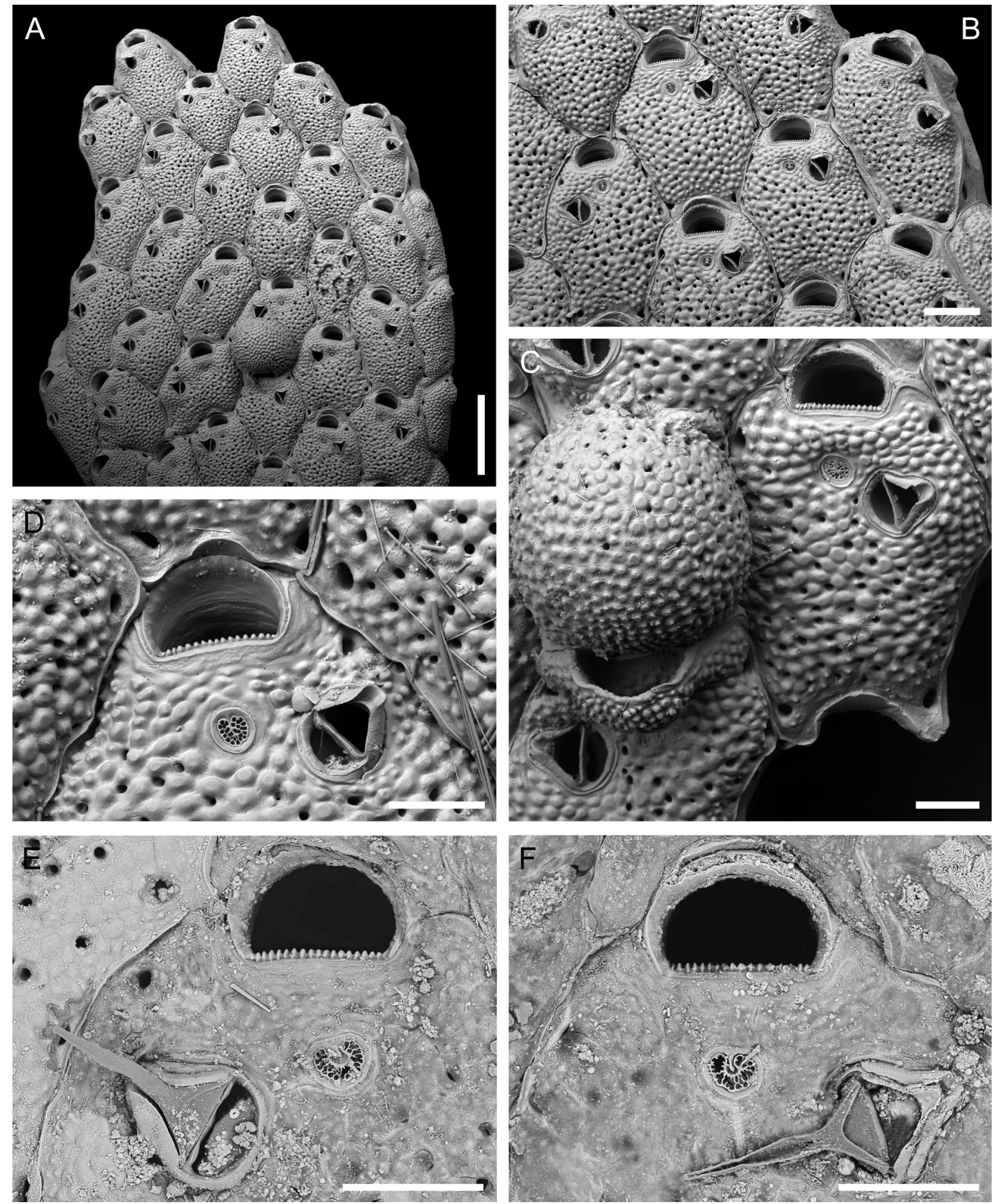

Fig. 8. Microporella ordoides sp. nov. A-D. Holotype NIWA 144883, Recent, New Zealand. A. Group of zooids at the branch tip. B. Close-up of autozooids. C. Close-up of the orifice, ascopore and adventitious avicularium. D. Close-up of an autozooid and ovicell. E-F. Paratype NIWA 119893 (unbleached), Recent, New Zealand. Two avicularia with closed and open mandible, respectively. Scale bars: A = $500 \mu \mathrm{m} ; \mathrm{B}=200 \mu \mathrm{m} ; \mathrm{C}-\mathrm{D}=100 \mu \mathrm{m} ; \mathrm{E}-\mathrm{F}=150 \mu \mathrm{m}$. 
Table 6. Measurements in $\mu \mathrm{m}$ of Microporella ordoides sp. nov., Recent, NZOI St. D35, New Zealand; holotype NIWA 144883.

\begin{tabular}{lccccc}
\hline & N (zooids, colonies) & Mean & SD & Min & Max \\
\hline ZL & 15,1 & 631 & \pm 58 & 522 & 729 \\
$\mathbf{Z W}$ & 15,1 & 487 & \pm 55 & 401 & 594 \\
OL & 15,1 & 99 & \pm 6 & 89 & 109 \\
OW & 15,1 & 158 & \pm 7 & 142 & 169 \\
AvL & 15,1 & 127 & \pm 12 & 99 & 141 \\
AvW & 15,1 & 106 & \pm 10 & 78 & 120 \\
OvL & 1,1 & 367 & - & - & - \\
OvW & 1,1 & 448 & - & - & - \\
\hline
\end{tabular}

OvicELLS. Large, bulbous, subglobular or a little longer than wide, personate or semipersonate, proximal arms forming bridge above ascopore; calcification of similar fabric to frontal calcification, continuous with frontal shield of distal zooid; pores small, sparse, mostly located near margins; partly formed ovicells common; orifice of ovicellate zooids hidden in frontal view; secondary orifice of personate ovicells boat-shaped with convex proximal and concave distal edge.

\section{Remarks}

This new species is extremely similar to Microporella ordo but differs in a sufficiently large number of characters to justify recognition as a separate species. Colonies of M. ordoides sp. nov. have narrow branches, contrasting with the broad fronds of $M$. ordo, and the growing edge is stepped rather than smooth. Differences in zooidal morphology include the greater number of pseudopores in the frontal shield of M. ordoides sp. nov., smaller outer teeth on the hingeline of the orifice, a horseshoe-shaped ascopore opening, personate or semi-personate ovicells containing fewer pores, and avicularia tending to be located more proximally than in M. ordo. Specimens of M. ordoides sp. nov. were collected off Campbell Island (New Zealand) on the Campbell Plateau at a depth of 159-435 m.

Microporella lingulata sp. nov.

urn:1sid:zoobank.org:act:A74444C9-3AA5-4A19-B08D-245169244E6A

Figs 9-10; Table 7

\section{Diagnosis}

Colony bifoliate, tongue-shaped. Ancestrula ascophoran with associated avicularium. Autozooids rounded quadrate. Frontal shield pustulose and pseudoporous; pustules flat-topped, pseudopores sometimes coalescent. Orifice transversely D-shaped; hingeline smooth; oral spines lacking. Ascopore reniform, opening crescentic, covered by a plate pierced by pores arranged in rows. Avicularium single, at level with ascopore, oriented laterally or slightly distolaterally; crossbar complete; rostrum subtriangular, not channeled. Ovicells not personate.

\section{Etymology}

From the Latin 'lingulata', meaning tongue-shaped and referring to the shape of the colonies. 


\section{Material examined}

\section{Holotype}

NEW ZEALAND • Unbleached specimen; Foveaux Strait; [4655.0’ S, $168^{\circ} 24.0$ E]; [53 m]; NZOI St. B263; Recent; NIWA 144886 (Fig. 9).

\section{Paratypes}

NEW ZEALAND • 1 specimen; same collection data as for holotype; NIWA 144887 (Fig. 10A-B) - 1 specimen; same collection data as for holotype; NIWA 144888 (Fig. 10C-D) 11 specimen; same collection data as for holotype; NIWA 144889 (Fig. 10E-F).

Additional material (not figured)

NEW ZEALAND • 2 specimens; same collection data as for holotype; NIWA 144890, 144891.
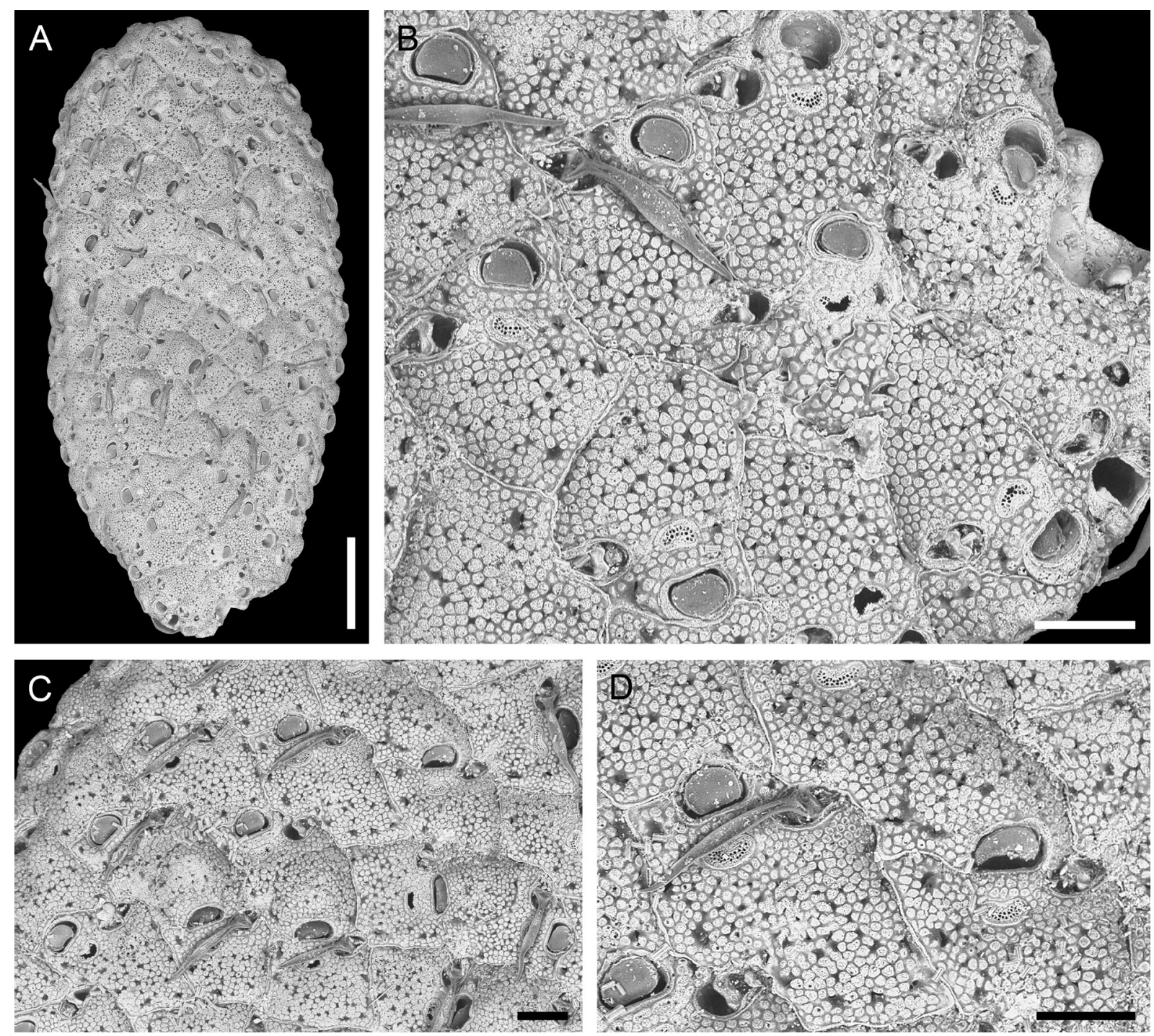

Fig. 9. Microporella lingulata sp. nov., holotype, NIWA 144886 (unbleached), Recent, Foveaux Strait, New Zealand. A. General view of the tongue-shaped colony. B. Apparent ancestrula and periancestrular zooids. C. Group of ovicellate and non-ovicellate zooids. Some avicularia show the long, lanceolate mandibles. D. Close-up of an autozooid, having the avicularian mandible open, and an ovicellate zooid (right). Scale bars: A $=1 \mathrm{~mm}$; B-D $=200 \mu \mathrm{m}$. 


\section{Description}

Colony. Erect, bifoliate, comprising a single, non-bifurcating branch, tongue-shaped, 4-6 $\mathrm{mm}$ long by $3-4 \mathrm{~mm}$ wide $(0.5-1 \mathrm{~mm}$ at the tip), proximal end rounded, distal end truncate forming growing edge; basally unattached; interzooidal communications not observed. Apparent ancestrula ascophoran in morphology (damaged in scanned examples), about $300 \times 185 \mu \mathrm{m}$, with an associated avicularium; located on one side of branch close to but not at proximal extremity of colony, oriented proximally. New buds at distal growing edge oriented obliquely to colony axis, facing distolaterally to the left on the left
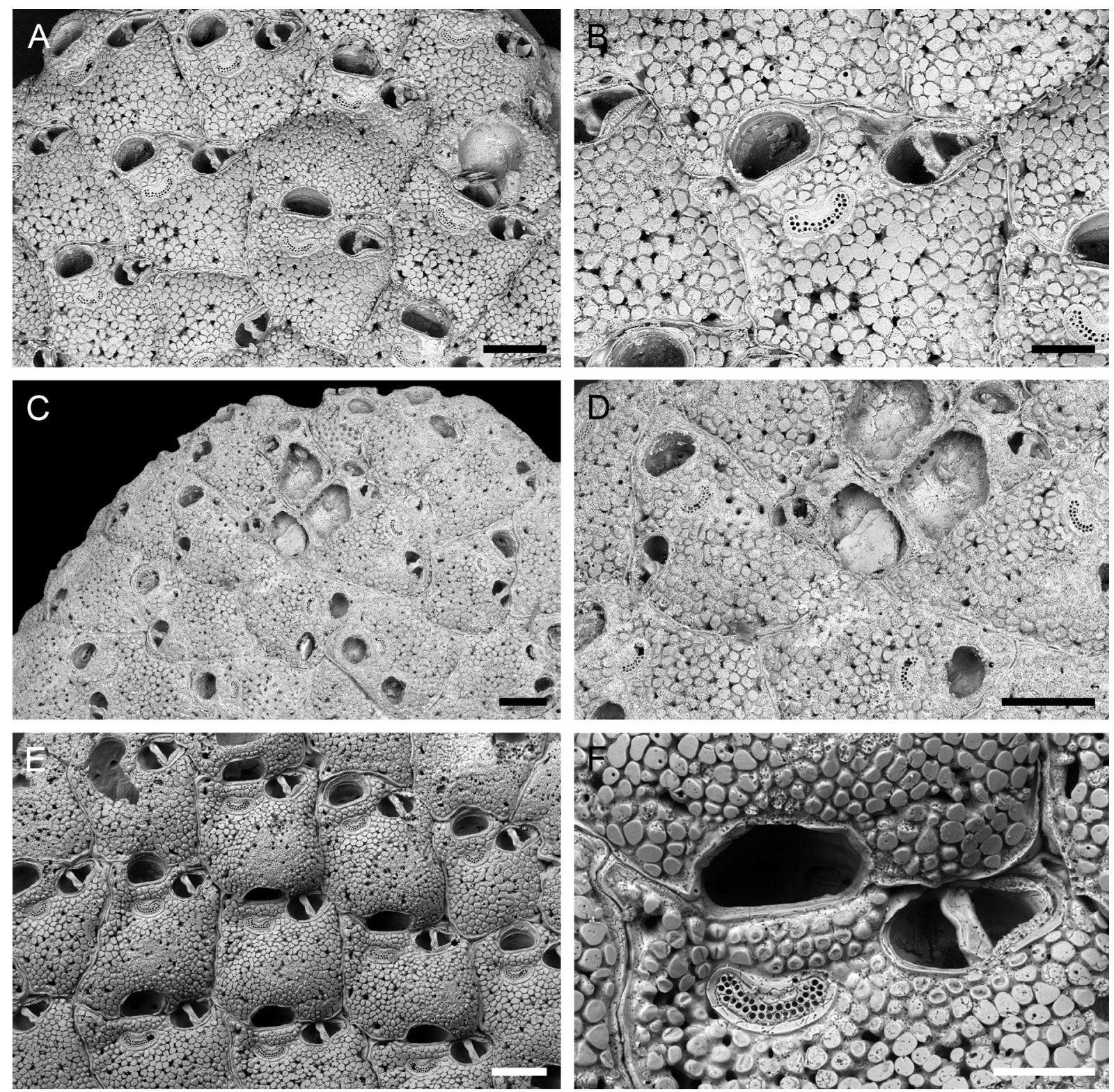

Fig. 10. Microporella lingulata sp. nov., paratypes, Recent, Foveaux strait, New Zealand. A-B. NIWA 144887. A. Group of ovicellate and non-ovicellate zooids. B. Close-up of an autozooid showing the reniform, cribrate ascopore. C-D. NIWA 144888. C. General view of the branch proximal tip including the ancestrular area. D. Close-up of damaged ancestrula and periancestrular zooids. E-F. NIWA 144889. E. Ovicellate zooids. F. Close-up of orifice, ascopore and avicularium in an ovicellate zooid. Scale bars: A, $\mathrm{C}-\mathrm{E}=200 \mu \mathrm{m} ; \mathrm{B}, \mathrm{F}=100 \mu \mathrm{m}$. 
Table 7. Measurements in $\mu \mathrm{m}$ of Microporella lingulata sp. nov., Recent, Foveaux Strait, New Zealand; paratypes NIWA 144887, 144888, 144889.

\begin{tabular}{lccccc}
\hline & N (zooids, colonies) & Mean & SD & Min & Max \\
\hline ZL & 20,3 & 563 & \pm 55 & 421 & 669 \\
ZW & 20,3 & 441 & \pm 52 & 342 & 570 \\
OL & 15,3 & 95 & \pm 10 & 83 & 115 \\
OW & 15,3 & 138 & \pm 19 & 118 & 180 \\
AvL & 20,3 & 174 & \pm 10 & 159 & 193 \\
AvW & 20,3 & 108 & \pm 8 & 96 & 127 \\
OvL & 15,3 & 268 & \pm 27 & 233 & 318 \\
OvW & 15,3 & 406 & \pm 36 & 347 & 468 \\
\hline
\end{tabular}

side and distolaterally to the right on the right side; zig-zag seam between left- and right-facing zooids approximately parallel to axis but typically displaced from midline.

Autozooids. Distinct with interzooidal boundaries marked by narrow grooves, usually rounded quadrate, slightly torqued, longer than wide (mean $\mathrm{L} / \mathrm{W}=1.28$ ). Frontal shield convex, pustulose, the pustules conspicuously flat-topped, about $20 \mu \mathrm{m}$ in diameter; marginal areolae numbering about 8 , elongate, larger at corners of zooids, ca $20-35 \mu \mathrm{m}$ long by 10-15 $\mu \mathrm{m}$ wide; non-marginal pseudopores located in grooves between flat-topped pustules, irregularly arranged, variable in number and size (diameter 10-20 $\mu \mathrm{m}$ ), sometimes coalescent.

ORIFICE. Transversely D-shaped, significantly wider than long, hingeline straight or slightly convex, without teeth or condyles; oral spines lacking; operculum smooth.

AsCOPORE FIELD. Bordered by a thick rim of gymnocystal calcification, located moderately close to orifice, about $70 \mu \mathrm{m}$ below, separated from it by non-porous cryptocystal calcification with smaller than average pustules; broad, reniform, 35-55 $\times 100-110 \mu \mathrm{m}$, opening crescentic, 10-15 $\times 70-85 \mu \mathrm{m}$, covered by a plate pierced by about $30-40$ circular pores arranged in two rows, sometimes three rows at the outer ends.

AvicUlarium. Single, moderately large, present in most autozooids, located on right of autozooids at the left side of colony and on the left of those at the right side; level with or distal of ascopore, oriented laterally or slightly disto-laterally; crossbar deep, distal edge straight, proximal edge scalloped; opesia semielliptical; rostrum short, subtriangular, the distal end rounded and without a channel. Mandible long, ca 315-450 $\mu \mathrm{m}$, lanceolate, pointed, slightly hooked, open examples mostly lying across ascopore. Intramural budding common in avicularia.

OvicELLS. Large, low in profile, not personate; calcification of identical fabric to frontal shield, continuous with frontal shield of distal zooid; pores irregularly scattered over surface; secondary orifice of ovicellate zooids shallower than infertile zooids.

\section{Remarks}

The ascopore of this new species is unusually wide compared with congeners, and the flat-topped cryptocystal pustules are another very notable feature. However, it is the peculiar tongue-shape of colonies that provides the easiest way of recognizing Microporella lingulata sp. nov. while at the same time posing questions about its mode of life. No substrate of attachment is visible, although it is possible 
that a small substrate is present but totally enveloped by later growth. Regardless, it is difficult to understand how adult colonies were supported as there are no indications of rhizoids to root the colonies into a particulate substratum, nor are rhizoids known in any other species of Microporella. Functional autozooids were evidently budded at equal rates on both sides of the branch, arguing against the idea that colonies rested horizontally on the sea-bed with one side down against the sediment. The most plausible options are either a vertical orientation with only the rounded proximal end embedded in the sediment, or the entire colony living interstitially within a coarse substratum. According to St. B263 sediment data, the seafloor at the exact locality that yielded the specimens comprises medium and fine sand (62.5 to $500 \mu \mathrm{m}$ particle size). Given the colonies are not rooted, it is possible that they just sit on the seafloor. The robust avicularian mandibles may have a supportive role, perhaps analogous to that in free-living lunulitiform bryozoans (e.g., Chimonides \& Cook 1981).

Microporella modesta sp. nov. urn:1sid:zoobank.org:act:18FA46FC-2D1B-4464-B5EC-34A6D51D9DAF

Fig. 11; Table 8

\section{Diagnosis}

Colony erect, bifoliate; branches narrow. Autozooids rhomboidal. Frontal shield pustulose and pseudoporous; pustules densely-packed. Orifice transversely D-shaped, over twice as wide as long; hingeline toothed, a large tooth at each extremity; sometimes a low cowl-like peristome developed distally; three or four oral spines. Ascopore reniform to elliptical, opening crescent-shaped, lined by denticles; ascopore hidden by prominent mucro in frontal view. Avicularium single, located proximally of ascopore, oriented distolaterally; crossbar complete; rostrum channelled. Ovicells not personate.

\section{Etymology}

From the Latin 'modesta', meaning modest, moderate and referring to the ascopore concealed beneath a mucro.

\section{Material examined}

\section{Holotype}

ALGERIA • Unbleached specimen; Yates Johnson leg.; Recent; NHMUK 1869.10.6.6a (Fig. 11A-C).

\section{Paratypes}

ALGERIA - 3 specimens; Same collection data as for holotype; NHMUK 1869.10.6.6b (Fig. 11D-F), 1869.10.6.6c (Fig. 11G), 1869.10.6.6d (Fig. 11H).

\section{Description}

Colony. Erect, bifoliate, branches narrow, strap-like, ca $5 \mathrm{~mm}$ wide with up to 15 linear series of alternating zooids on each side; growing edge stepped; interzooidal communications not observed.

Autozooids. Distinct with interzooidal boundaries marked by a narrow groove between salient vertical walls of adjacent zooids, rhomboidal, longer than wide (mean $\mathrm{L} / \mathrm{W}=1.33$ ). Frontal shield convex, pustulose, the pustules densely-packed and up to $20 \mu \mathrm{m}$ in diameter; marginal areolae numbering about 6, not always differentiated from pseudopores, sometimes elongate, ca $30 \mu \mathrm{m}$ long; pseudopores circular, numbering up to about 50, arranged semi-regularly in grooves between pustules (diameter 10-25 $\mu \mathrm{m}$ ).

ORIFICE. Transversely D-shaped, over twice as wide as long, hingeline straight or slightly concave, equipped with a large tooth close to each end and numerous tiny teeth in between; low cowl-like peristome sometimes developed distally around orifice; three or four oral spines (diameter 10-15 $\mu \mathrm{m}$ ), a 
Table 8. Measurements in $\mu \mathrm{m}$ of Microporella modesta sp. nov., Recent, Foveaux Strait, New Zealand; holotype NHMUK 1869.10.6.6a, paratypes NHMUK 1869.10.6.6b, 1869.10.6.6c.

\begin{tabular}{lccccc}
\hline & N (zooids, colonies) & Mean & SD & Min & Max \\
\hline ZL & 20,3 & 630 & \pm 99 & 499 & 803 \\
ZW & 20,3 & 472 & \pm 103 & 298 & 709 \\
OL & 20,3 & 83 & \pm 16 & 58 & 108 \\
OW & 20,3 & 171 & \pm 23 & 141 & 214 \\
AvL & 20,3 & 100 & \pm 14 & 73 & 123 \\
AvW & 20,3 & 108 & \pm 8 & 96 & 127 \\
OvL & 20,3 & 302 & \pm 47 & 218 & 366 \\
OvW & 20,3 & 359 & \pm 60 & 281 & 460 \\
\hline
\end{tabular}

spine just above each proximolateral corner of orifice plus a single distal median spine or spines inwards of the two distolateral corners.

ASCOPORE FIELD. As a flared, raised area of gymnocystal calcification, located moderately close to orifice, ca $40 \mu \mathrm{m}$ below, separated from it by non-porous pustulose cryptocyst field; reniform to transversely elliptical, $25 \times 60 \mu \mathrm{m}$, opening crescent-shaped, $5 \times 30 \mu \mathrm{m}$, lined by denticles; prominent mucro proximal of ascopore with spine-like or flap-like overhang hiding ascopore in frontal aspect.

Avicularium. Single, moderately large, present in the majority of autozooids on side closest to branch margin, positioned proximally of ascopore, close to mucro, oriented distolaterally; crossbar complete; opesia semielliptical, shallow; rostrum short, subtriangular, rounded distally and channelled. Mandible long, about 250-320 $\mu \mathrm{m}$, pointed, toothed, lying proximally of ascopore when open. Intramural budding often observed in avicularia.

OvicELLS. Moderately large, subglobular or rounded quadrate, not personate, proximal arms forming bridge above ascopore; calcification of similar fabric to cryptocyst but pustules smaller and more closely-spaced, continuous with frontal shield of distal zooid; pseudopores small, peripheral only, those near margins aligned in radial rows; orifice of ovicellate zooids partly hidden in frontal view.

\section{Remarks}

This is the only bifoliate species of Microporella known from the Mediterranean (coast of Algeria). The presence of a mucro projecting over the ascopore enables M. modesta sp. nov. to be readily distinguished from its bifoliate congeners described above, as well as the encrusting European species of Microporella (i.e., M. ciliata (Pallas, 1766), M. marsupiata (Busk, 1860), M. appendiculata (Heller, 1867)). The

Fig. 11 (opposite page). Microporella modesta sp. nov., Recent, Algeria. A-C. Holotype NHMUK 1869.10.6.6a (unbleached). A. General view of the branch tip. B. Group of autozooids at the branch tip. C. Close-up of the orifice with four oral spine bases, suboral mucro concealing the ascopore, and avicularium with the long, pointed mandible open. D-F. NHMUK 1869.10.6.6b. D. Group of zooids, mostly ovicellate. E. Close-up of ovicells. F. Close-up of an orifice and two avicularia, the one on the left with intramural budding. G. NHMUK 1869.10.6.6c, ascopore. H. NHMUK 1869.10.6.6d, damaged zooid with two avicularia on the left zooidal margin. Scale bars: A, D = $1 \mathrm{~mm} ; \mathrm{B}=200 \mu \mathrm{m} ; \mathrm{C}, \mathrm{F}-\mathrm{H}=$ $100 \mu \mathrm{m} ; \mathrm{E}=500 \mu \mathrm{m}$. 

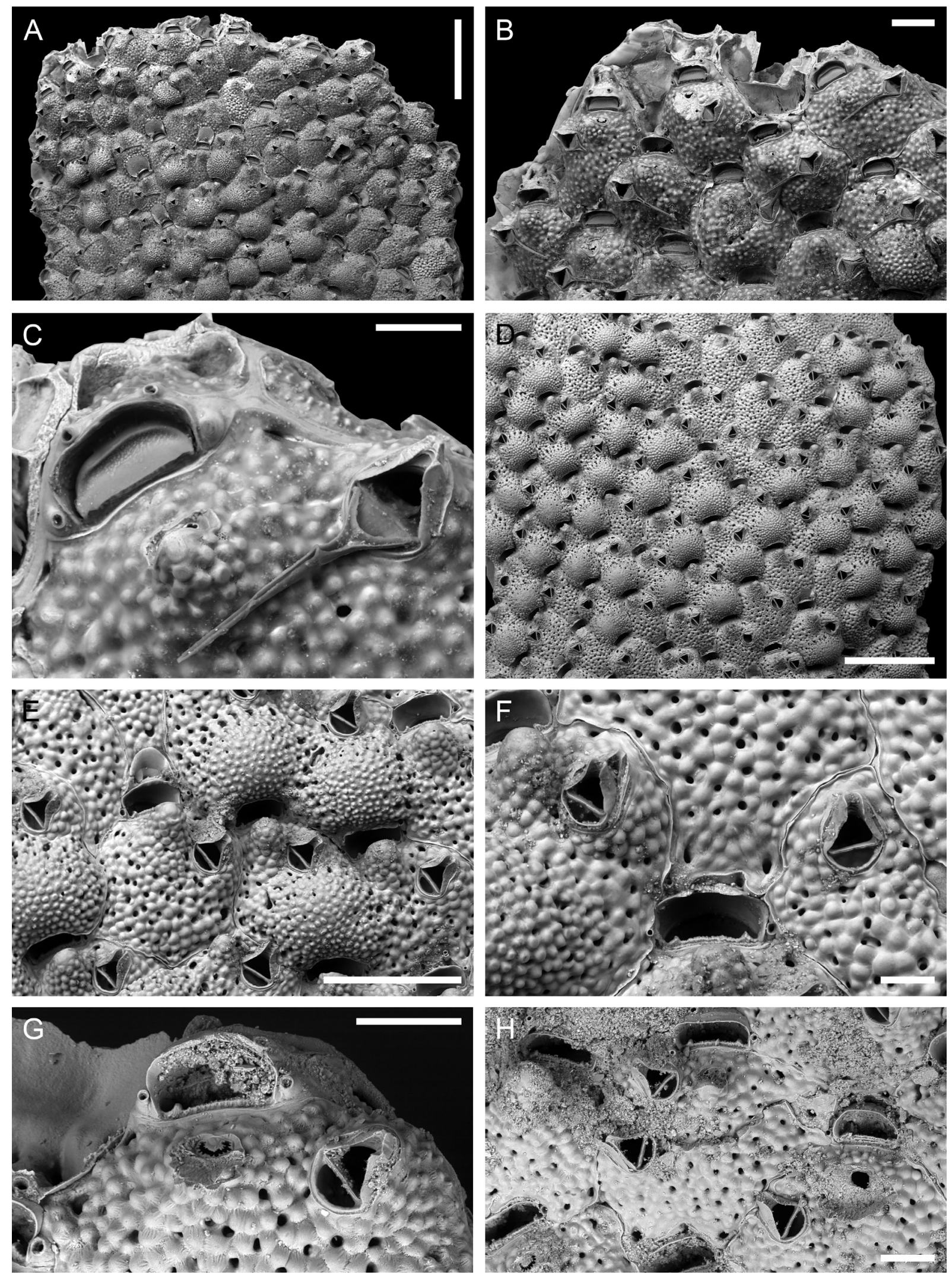
new species is also unusual in possessing oral spines which are mostly lacking in bifoliate species of Microporella, another exception being M. hastigera.

\section{Microporella sp. 1}

Fig. 12; Table 9

\section{Material examined}

NEW ZEALAND • Single infertile fragment; SW of South Island, Puysegur Bank; [46.43 $\left.\mathrm{S}, 166.08^{\circ} \mathrm{E}\right]$; depth 187 m; Recent; NHM-UIO BLEED 151 (voucher specimen).

\section{Description}

Colony. Erect, bifoliate, branches narrow; fragment available ca $3 \mathrm{~mm}$ wide with up to six linear series of alternating zooids on each side; interzooidal communications through multiporous septula visible at colony growing edge.

AutozooIDs. Distinct with interzooidal boundaries marked by thin band of slightly raised calcification on either side of a narrow groove, rounded rectangular to hexagonal, longer than wide (mean $\mathrm{L} / \mathrm{W}=$ 1.31). Frontal shield convex, pustulose, the pustules flat-topped, varying in size; marginal areolae numbering about $10-12$, usually elongate $(25-40 \mu \mathrm{m}$ long) especially at zooidal corners, sometimes indistinguishable from frontal pores along lateral sides of the zooids; non-marginal pseudopores about 40-60, small (diameter 10-15 $\mu \mathrm{m}$ ), irregularly scattered among pustules, sometimes coalescent.

ORIFICE. Transversely D-shaped, significantly wider than long, hingeline with about 14-18 equal-sized teeth; oral spines lacking. Operculum smooth.

ASCOPORE FIELD. As a narrow band of gymnocystal calcification, at approximately same level as orifice but beneath level of adjacent frontal shield, located at ca 55-75 $\mu \mathrm{m}$ from the orifice hingeline, separated from it by non-porous pustulose cryptocyst; circular (diameter 50-60 $\mu \mathrm{m}$ ) to transversely elliptical (55 $\mu \mathrm{m}$ long by $80 \mu \mathrm{m}$ wide), opening C-shaped, $10 \times 50 \mu \mathrm{m}$, with tiny radial denticles, and a circular tongue projecting from the distal edge.

Avicularium. Usually single, rarely paired, moderately large, present in all autozooids, positioned at level with the ascopore, oriented distolaterally, usually at about $45^{\circ}$ to the long axis of the supportive autozooid; crossbar calcified; opesia semielliptical; rostrum short, subtriangular with concave sides, the distal end rounded, distinct channel present. Mandible 150-180 $\mu \mathrm{m}$ long, narrow and pointed. Multiple intramural buds observed in avicularia.

OvicELls. Not observed.

\section{Remarks}

Among all bifoliate congeners, Microporella sp. 1 mostly resembles M. hyadesi. The two species share a transversely D-shaped orifice with equal-sized teeth in the hingeline, the characters of the ascopore and the appearance of the frontal shield made of flat-topped pustules. Differences include: the shape of the zooids (mean $\mathrm{L} / \mathrm{W}=1.67$ and 1.31, respectively) which are rectangular and flat in $M$. hyadesi, rhomboidal to hexagonal and convex in Microporella sp. 1; the avicularium is more laterally oriented and has a wider channel in the rostrum than M. hyadesi. The two species also differ in their geographical distributions. The single available fragment of Microporella sp. 1 was found at Puysegur Bank, south west of South Island of New Zealand at a depth of $187 \mathrm{~m}$, while M. hyadesi is a South Atlantic species found at a depth of 49-341 m (Hayward \& Ryland 1990). 

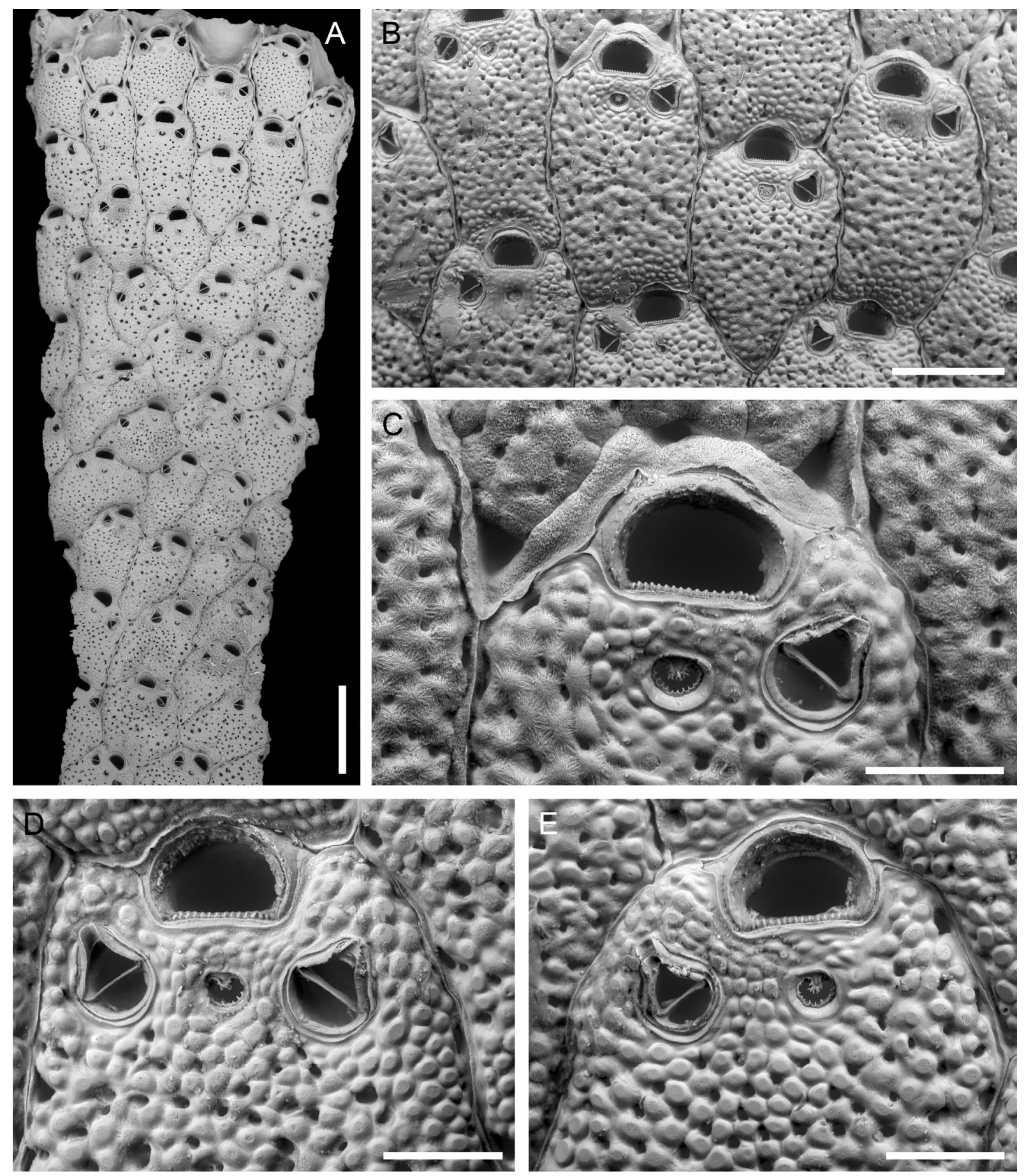

Fig. 12. Microporella sp. 1, BLEED 151, Recent, Puysegur Bank. A. General view of the branch fragment. B. Group of autozooids. C. Close-up of orifice, ascopore and avicularium. D. Close-up of an autozooid with paired avicularia. E. Close-up of an autozooid with avicularium showing intramural budding. Scale bars: $A=1 \mathrm{~mm} ; \mathrm{B}=500 \mu \mathrm{m} ; \mathrm{C}-\mathrm{E}=150 \mu \mathrm{m}$. 
Table 9. Measurements in $\mu \mathrm{m}$ of Microporella sp. 1, Recent, Puysegur Bank, New Zealand; voucher specimen BLEED 151.

\begin{tabular}{lccccc}
\hline & N (zooids, colonies) & Mean & SD & Min & Max \\
\hline ZL & 20,1 & 736 & \pm 78 & 599 & 899 \\
$\mathbf{Z W}$ & 20,1 & 562 & \pm 94 & 417 & 776 \\
OL & 18,1 & 114 & \pm 6 & 101 & 125 \\
OW & 18,1 & 183 & \pm 9 & 163 & 200 \\
AvL & 20,1 & 135 & \pm 11 & 113 & 151 \\
AvW & 20,1 & 107 & \pm 11 & 81 & 126 \\
\hline
\end{tabular}

\section{Discussion}

Although uncommon, erect bifoliate growth can be inferred to have evolved on several occasions in Microporella from ancestral species with encrusting colonies. On the basis of zooidal features, the two fossil bifoliate species described here appear to be closely related, as do four of the seven Recent bifoliate species. The two North American fossil species, the Miocene M. bifoliata and the Pliocene M. tanyae sp. nov., are very similar yet specifically distinct species, chronologically separated by ca 7

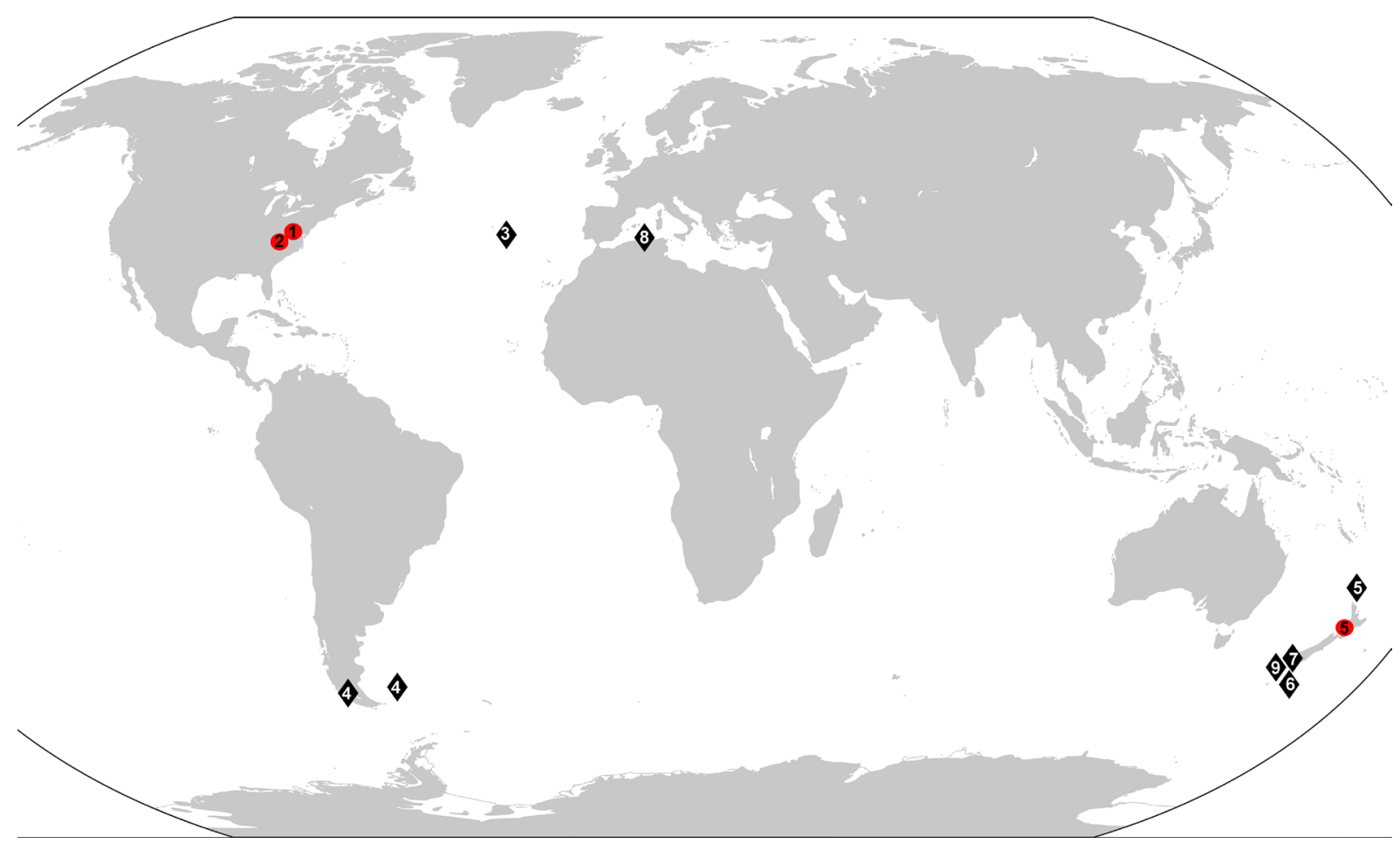

Fig. 13. Geographical distribution of the nine bifoliate species of Microporella Hincks, 1877 known to date. Red circles indicate fossil occurrences, while black lozenges indicate living records. $1=$ M. bifoliata, Miocene, Maryland, USA; $2=$ M. tanyae sp. nov., Pliocene, Virginia, USA; $3=$ M. hastigera (Busk, 1884), Recent, Azores, Central Atlantic; $4=$ M. hyadesi (Jullien, 1888), Recent, Falklands Islands and Magellan Strait, South Atlantic; $5=$ M. ordo Brown, 1952, Pleistocene (Wanganui Basin) to Recent (Spirits Bay) New Zealand; $6=$ M. ordoides sp. nov., Recent, Campbell Plateau, New Zealand; $7=$ M. lingulata sp. nov., Recent, Foveaux Strait, New Zealand; $8=$ M. modesta sp. nov., Recent, Mediterranean off Algeria; $9=M$. sp. 1, Recent, Puysegur Bank, New Zealand. 
million years (ca 12 vs 5 million years old, respectively). Microporella hyadesi, M. ordo, M. ordoides sp. nov. and $M$. sp. 1 show sufficient similarities to one another and differences from other species of Microporella indicating that they may represent a distinct clade, a hypothesis that could be tested when molecular sequence data become available. The other three Recent bifoliate species (M. hastigera, M. lingulata sp. nov. and M. modesta sp. nov.) have little in common, except for being bifoliate, and are probably more closely related to different encrusting species of Microporella than they are to other bifoliate species of Microporella.

The two exclusively fossil species are both recorded from North American Cenozoic deposits. Four out of the seven living species are distributed in New Zealand waters (M. ordo, M. ordoides, M. lingulata, $M$. sp. 1), M. hyadesi and M. hastigera were reported from several close localities in the South and Central Atlantic respectively, while M. modesta sp. nov. is a Mediterranean species from off Algeria (Fig. 13). Among these, only M. ordo was first described from Pleistocene deposits in the Wanganui Basin, New Zealand.

Two other genera of Microporellidae - Diporula and Flustramorpha Gray, 1872 - comprise Microporella-like species having erect colonies with cylindrical and bifoliate branches, respectively. However, colony growth-form alone seems a feeble character to justify the distinction among the three genera. In fact, most erect bilaminate colonies start with a more or less developed encrusting base before growing as erect bilaminate sheets back-to-back. For example, Microporella tanyae sp. nov. starts with an extended encrusting base completely wrapping the shelly substrate (see Fig. 2). In addition to the colony growth-form, Hincks (1880: 220) emphasized the different structure of the orifice, semicircular in Microporella, horseshoe-shaped in Diporula. The shape of the orifice may also be somehow variable. In encrusting species of Microporella from Hokkaido (Japan), the shape of the orifice varies from higharched semicircular to transversely D-shaped, to oval (Suwa \& Mawatari 1998).

The diagnosis of the genus Microporella given by Hayward \& Ryland (1999: 292) includes an imperforate ooecium and the presence of conspicuous basal pore-chambers, while in the diagnosis of Diporula (Hayward \& Ryland 1999: 302) the ooecium is perforate and basal pore-chambers are substituted by small multiporous septula. However, pseudopores also occur in the ooecium of many encrusting species of Microporella, including the type species Microporella ciliata (see Kukliński \& Taylor 2008: fig. 1c). The presence of small multiporous mural septula in lateral walls has been also observed in erect bifoliate species of Microporella (e.g., Microporella ordo, Fig. 7D).

Microporella hastigera offers an example of how the boundaries among Microporella, Diporula and Flustramorpha can be indistinct. Busk (1884: 135), who originally described Microporella hastigera as Flustramorpha, expressed his doubts about the separation of this genus from Microporella based solely on colony growth-form, and suggested that Flustramorpha may be a subgenus of Microporella. Subsequently, M. hastigera was placed in Diporula and eventually in Microporella by Calvet (1931) and d'Hondt (1975), who regarded Diporula as a synonym of Microporella.

A meaningful phylogenetic analysis of Microporella and closely-related genera (i.e., Diporula and Flustramorpha) currently in progress will be of paramount importance to resolve the phylogenetic relationships of microporellids and offer robust evidence for formal synonymy of these genera.

\section{Acknowledgements}

We thank Mary Spencer Jones (Department of Life Sciences, Natural History Museum, London) for arranging the loan of the specimens in her care; JoAnn Sanner (Department of Paleobiology, National Museum of Natural History, Smithsonian Institution, Washington D.C.) for providing SEM images of Microporella bifoliata syntypes; Björn Berning (Oberösterreichisches Landesmuseum, Linz) for 
providing detailed information and discussion on Microporella hastigera. EDM was supported by the European Research Council (ERC) under the European Union's Horizon 2020 Research and Innovation Programme (grant agreement no. 724324 to Lee Hsiang Liow). Comments from Antonietta Rosso (University of Catania) and Björn Berning (Oberösterreichisches Landesmuseum, Linz) helped to improve the originally submitted manuscript.

\section{References}

Andrews G.W. 1988. A revised marine diatom zonation for Miocene strata of the southeastern United States. U.S. Geological Survey Professional Paper 1481: 1-29. https://doi.org/10.3133/pp1481

Brown D.A. 1952. The Tertiary cheilostomatous Polyzoa of New Zealand. Trustees of the British Museum (Natural History), London. https://doi.org/10.5962/bhl.title.118779

Busk G. 1884. Report on the Polyzoa Collected by H.M.S. Challenger During the Years 1873-1876. Part 1. The Cheilostomata. Report on the scientific results of the voyage of the H.M.S. "Challenger", Zoology 10 (V), Neill, Edinburgh. https://doi.org/10.5962/bhl.title.6513

Calvet L. 1907. Bryozoaires. In: Expéditions scientifiques du "Travailleur" et du "Talisman" pendant les Années 1880-1883 8: 355-495. G. Masson, Paris.

Calvet L. 1931. Bryozoaires provenant des campagnes scientifiques du Prince Albert $1^{\text {er }}$ de Monaco. Résultats des Campagnes scientifiques du Prince Albert $1^{\text {er }}$ de Monaco 83: 1-152.

Canu F. \& Bassler R.S. 1923. North American later Tertiary and Quaternary Bryozoa. United States National Museum Bulletin 125: 1-302. https://doi.org/10.5479/si.03629236.125.i

Chimonides P.J. \& Cook P.L. 1981. Observations on living colonies of Selenaria (Bryozoa, Cheilostomata). II. Cahiers de Biologie marine 22: 207-219.

Di Martino E., Taylor P.D., Gordon D.P. \& Liow L.H. 2017. New bryozoan species from the Pleistocene of the Wanganui Basin, North Island, New Zealand. European Journal of Taxonomy 345: 1-15.

https://doi.org/10.5852/ejt.2017.345

Harmelin J.-G., Ostrovsky A.N., Cáceres-Chamizo J. \& Sanner J. 2011. Bryodiversity in the tropics: taxonomy of Microporella species (Bryozoa, Cheilostomata) with personate maternal zooids from Indian Ocean, Red Sea and southeast Mediterranean. Zootaxa 2798: 1-30.

https://doi.org/10.11646/zootaxa.2798.1.1

Hayward P.J. \& Ryland J.S. 1990. Some Antarctic and Subantarctic species of Microporellidae (Bryozoa: Cheilostomata). Journal of Natural History 24: 1263-1287.

https://doi.org/10.1080/00222939000770751

Hayward P.J. \& Ryland J.S. 1999. Cheilostomatous Bryozoa. Part 2. Hippothoidea - Celleporoidea. Synopses of the British Fauna (New Series): 14, Field Studies Council, Shrewsbury.

Hincks T. 1880. A history of the British Marine Polyzoa. Van Voorst, London. https://doi.org/10.5962/bhl.title.31555

d'Hondt J.-L. 1975. Bryozoaires Cténostomes et Cheilostomes (Cribrimorphes et Escharellidae exceptés) provenant des dragages de la campagne océanographique Biaçores du "Jean Charcot". Bulletin du Muséum national d'histoire naturelle 299: 553-600.

Jullien J. 1888. Bryozoaires. Mission scientifique du Cap Horn 1882-1883 6: 1-92.

Jullien J. \& Calvet L. 1903. Bryozoaires provenant des campagnes de l'Hirondelle (1886-1888). Résultats des Campagnes scientifiques du Prince de Monaco 23: 1-188. 
Kukliński P. \& Taylor P.D. 2008. Arctic species of the cheilostome bryozoan Microporella, with a redescription of the type species. Journal of Natural History 42: 1893-1906.

https://doi.org/10.1080/00222930802126904

López-Gappa J.J. 1975. Briozoos marinos de Tierra del Fuego. I. Physis, Buenos Aires 34: 433-439.

López-Gappa J.J. \& Lichtschein V. 1990. Los Briozoos coleccionados por el B/I Shinkai Maru en la plataforma continental Argentina. Servicio de Hidrografia Naval.

Moyano G.H.I. 2000. Bryozoa from the magellanic continental slope near Cape Horn: an unexpected collection. In: Herrera-Cubilla A. \& Jackson J.B.C. (eds) Proceedings of the $11^{\text {th }}$ International Bryozoology Association Conference: 298-304. Smithsonian Tropical Research Institute, Balboa, R.P.

Powell N.A. 1967. Polyzoa (Bryozoa) - Ascophora - from north New Zealand. Discovery Reports 34: 199-393.

Suwa T. \& Mawatari S.F. 1998. Revision of seven species of Microporella (Bryozoa, Cheilostomatida) from Hokkaido, Japan, using new taxonomic characters. Journal of Natural History 32: 895-922. https://doi.org/10.1080/00222939800770461

Taylor P.D. \& Mawatari S.F. 2005. Preliminary overview of the cheilostome bryozoan Microporella. In: Moyano G.H.I., Cancino J.M. \& Wise Jackson P.N. (eds) Bryozoan Studies 2004: 329-339. A.A. Balkema Publishers, Leiden, London, New York, Philadelphia, Singapore.

Thornely L.R. 1912. Marine Polyzoa of the Indian Ocean. Transactions of the Linnean Society of London 15: 137-157. https://doi.org/10.1111/j.1096-3642.1912.tb00095.x

Ulrich E.O. \& Bassler R.S. 1904. Miocene. Bryozoa. Maryland Geological Survey 1904: 404-429.

Waters A.W. 1888. Supplementary report on the Polyzoa collected by H.M.S. "Challenger" during the years 1873-1876. Report on the Scientific Results of the Voyage of the H.M.S. "Challenger", Zoology 31: $1-41$.

Wilson M.A. \& Taylor P.D. 2006. Predatory drill holes and partial mortality in Devonian colonial metazoans. Geology 34: 565-568.

Manuscript received: 25 March 2020

Manuscript accepted: 25 May 2020

Published on: 2 July 2020

Topic editor: Christian de Muizon

Desk editor: Radka Rosenbaumová

Printed versions of all papers are also deposited in the libraries of the institutes that are members of the EJT consortium: Muséum national d'histoire naturelle, Paris, France; Meise Botanic Garden, Belgium; Royal Museum for Central Africa, Tervuren, Belgium; Royal Belgian Institute of Natural Sciences, Brussels, Belgium; Natural History Museum of Denmark, Copenhagen, Denmark; Naturalis Biodiversity Center, Leiden, the Netherlands; Museo Nacional de Ciencias Naturales-CSIC, Madrid, Spain; Real Jardín Botánico de Madrid CSIC, Spain; Zoological Research Museum Alexander Koenig, Bonn, Germany; National Museum, Prague, Czech Republic. 